\title{
Taxonomy and palaeoecology of two widespread western Eurasian Neogene sclerophyllous oak species: Quercus drymeja Unger and Q. mediterranea Unger
}

\author{
Thomas Denk $^{\mathrm{a}, *}$, Dimitrios Velitzelos ${ }^{\mathrm{b}}$, Tuncay H. Güner ${ }^{\mathrm{c}}$, Johannes M. Bouchal ${ }^{\mathrm{a}, \mathrm{d}}$, \\ Friðgeir Grímsson ${ }^{\mathrm{d}}$, Guido W. Grimm ${ }^{\mathrm{d}, \mathrm{e}}$ \\ a Swedish Museum of Natural History, Department of Palaeobiology, Box 50007, 10405 Stockholm, Sweden \\ b National and Kapodistrian University of Athens, Faculty of Geology and Geoenvironment, Department of Historical Geology and Paleontology, Panepistimiopolis, Athens 15784, Greece \\ c Istanbul University, Faculty of Forestry, Department of Forest Botany, 34473 Bahceköy, Istanbul, Turkey \\ ${ }^{\mathrm{d}}$ University of Vienna, Department of Palaeontology, 1090 Vienna, Austria \\ e Unaffiliated, 45100 Orléans, France
}

\section{A R T I C L E I N F O}

\section{Article history:}

Received 31 May 2016

Accepted 30 January 2017

Available online 10 February 2017

\section{Keywords:}

Quercus Group Ilex

Plant fossil

Modern analogue

Palaeoecology

Niche evolution

\begin{abstract}
A B S T R A C T
Sclerophyllous oaks (genus Quercus) play important roles in Neogene ecosystems of south-western Eurasia. Modern analogues ('nearest living relatives') for these oaks have been sought among five of six infrageneric lineages of Quercus, distributed across the entire Northern Hemisphere. A revision of leaf fossils from lower Miocene to Pliocene deposits suggests that morphotypes of the Quercus drymeja complex are very similar to a number of extant Himalayan, East Asian, and Southeast Asian species of Quercus Group Ilex and may indicate subtropical, relatively humid conditions. Quercus mediterranea comprises leaf morphotypes that are encountered in modern Mediterranean species of Quercus Group Ilex, but also in Himalayan and East Asian members of this group indicating fully humid or summer-wet conditions. The fossil taxa Quercus drymeja and Q. mediterranea should be treated as morphotype complexes, which possibly comprised different biological species at different times. Quercus mediterranea, although readily recognizable as a distinct morphotype in early to late Miocene plant assemblages, may in fact represent small leaves of the same plants that constitute the Quercus drymeja complex. Based on the available evidence, the species forming the $Q$. drymeja complex and Q. mediterranea thrived in fully humid or summer-wet climates. The onset of the modern vegetational context of Mediterranean sclerophyllous oaks is difficult to trace, but may have been during the latest Pliocene/early Pleistocene.
\end{abstract}

(c) 2017 Elsevier B.V. All rights reserved.

\section{Introduction}

Quercus (oaks, Fagaceae) is among the most important tree genera in the Northern Hemisphere. With about 400-500 species, it is the largest genus in the order Fagales (Govaerts and Frodin, 1998). Species are distributed in temperate and subtropical regions; the northern limit of their distribution corresponds to the transition from snow climates with warm summers to snow climates with cool summers ( $D f b$ to $D f c$, and $D w b$ to $D w c$ climates according to the Köppen-Geiger classification; Kottek et al., 2006; Peel et al., 2007). Recent molecular phylogenetic and morphological studies recovered two well-supported main lineages within oaks, one comprising the white oaks (Quercus Group Quercus),

\footnotetext{
* Corresponding author.

E-mail address: thomas.denk@nrm.se (T. Denk).
}

red oaks (Quercus Group Lobatae) and golden-cup oaks (Quercus Group Protobalanus), whereas the other group comprises the cyclecup oaks (Quercus Group Cyclobalanopsis), the Cerris oaks (Quercus Group Cerris) and the Ilex oaks (Quercus Group Ilex; Denk and Grimm, 2010; Hubert et al., 2014; Hipp et al., 2015; Simeone et al., 2016). Quercus Groups Lobatae and Protobalanus are presently confined to North and Central America and Quercus Group Quercus occurs throughout the Northern Hemisphere, while Quercus Groups Ilex, Cerris and Cyclobalanopsis are Eurasian. These infrageneric groups are also recognized using pollen morphology (Denk and Grimm, 2009; Denk and Tekleva, 2014). In contrast, similar leaf morphologies have evolved in parallel in different groups. For example, the western North American golden-cup oaks and the American white oaks of section Virentes are only distantly related to species of the Eurasian Ilex oaks, but have morphologically highly similar evergreen leaves (Flora of North America Editorial Committee, 1997; Flora of China Editorial Committee, 1999; Menitsky, 2005). 
In the present study, we assess the taxonomy of two western Eurasian Neogene sclerophyllous leaf fossil-species of oaks and compare it to evidence from dispersed pollen and from the carpological record.

\subsection{The fossil record of sclerophyllous oaks in Europe}

In a seminal study, Unger (1841-1847) described two species of sclerophyllous oaks from middle Miocene deposits of Parschlug, Austria, Quercus drymeja Unger and Q. mediterranea Unger. Unger considered the taxonomic affinity of $Q$. drymeja to be with the western Asian Q. libani G.Olivier (Quercus Group Cerris), the Mexican and Central American $Q$. lancifolia Schlechter et Chamisso, and mainly with the Mexican and Central American Q. xalapensis Bonpland (both Quercus Group Lobatae, red oaks). In contrast, he considered $Q$. mediterranea as closely similar to the Mediterranean $Q$. pseudococcifera Desfontaines (= Q. coccifera L.; Quercus Group Ilex). Kvaček et al. (2002) investigated late Miocene plant fossils from northern Greece and based on epidermal features (almost hairless abaxial leaf surface with only dispersed massive trichome bases) also suggested that $Q$. mediterranea belongs to the " $Q$. coccifera group". They noticed that distinguishing features of the leaf epidermis are shared between $Q$. mediterranea and $Q$. drymeja, but nevertheless compared the latter with the extant Mexican red oaks Q. sartorii Liebmann and Q. xalapensis. Kovar-Eder et al. (2004) re-studied the type material of $Q$. drymeja and $Q$. mediterranea from middle Miocene deposits of Parschlug and distinguished one additional sclerophyllous oak, Q. zoroastri Unger (1850). They agreed on the relationship between $Q$. mediterranea and the modern $Q$. coccifera, but did not indicate particular relationships of $Q$. drymeja and $Q$. zoroastri with modern oak species. More recently, Kvaček et al. (2011) studied middle Miocene leaf assemblages from southwestern France with abundant
Q. drymeja and $Q$. mediterranea. They noticed that although the leaf epidermis of $Q$. mediterranea matches that of the extant $Q$. coccifera (Kvaček et al., 2002), the leaf shape, size, and tooth architecture differ. For Q. drymeja, they found identical leaf epidermal features in the material from southwestern France and the material from northern Greece. Most recently, Deng et al. (2017) investigated all living members of Group Ilex and concluded that based on the scanty record of leaf epidermal characteristics of Q. drymeja most similarities are with "less hairy species in mesophytic and broadleaved evergreen forests, e.g., Q. cocciferoides and Q. baronii." (Deng et al., 2017, p. 33).

Notably, the records of $Q$. drymeja and Q. mediterranea have been substantially expanded after their original publication and currently cover an area from Spain to Georgia in western Eurasia and a stratigraphic range from lower Miocene to Pliocene (e.g. Givulescu and Ghiurca, 1969; Knobloch and Velitzelos, 1986a; Kvaček et al., 1993; Kvaček et al., 2002; Velitzelos, 2002; Velitzelos et al., 2014; Maps 1,2).

In view of the great morphological variability among leaf fossils assigned to $Q$. drymeja and the large stratigraphic range of this fossil species, ca. $19 \mathrm{Ma}$ to ca. $5 \mathrm{Ma}$ (see, e.g. Velitzelos et al., 2014; Table 1), we were interested in assessing the morphological coherence of this taxon across its geographical and stratigraphical range as this may have implications for inferring their closest modern relatives (commonly called nearest living relatives). In addition, we were interested in the systematic relationships of the two fossil-species $Q$. drymeja and Q. mediterranea. We used a modern phylogenetic framework established for oaks, which includes a time calibrated phylogeny for the genus (Manos et al., 2001; Denk and Grimm, 2010; Hubert et al., 2014; Hipp et al., 2015). Finally, we discuss how niche evolution in oak lineages may impact palaeoecological inferences using nearestliving-relative approaches.

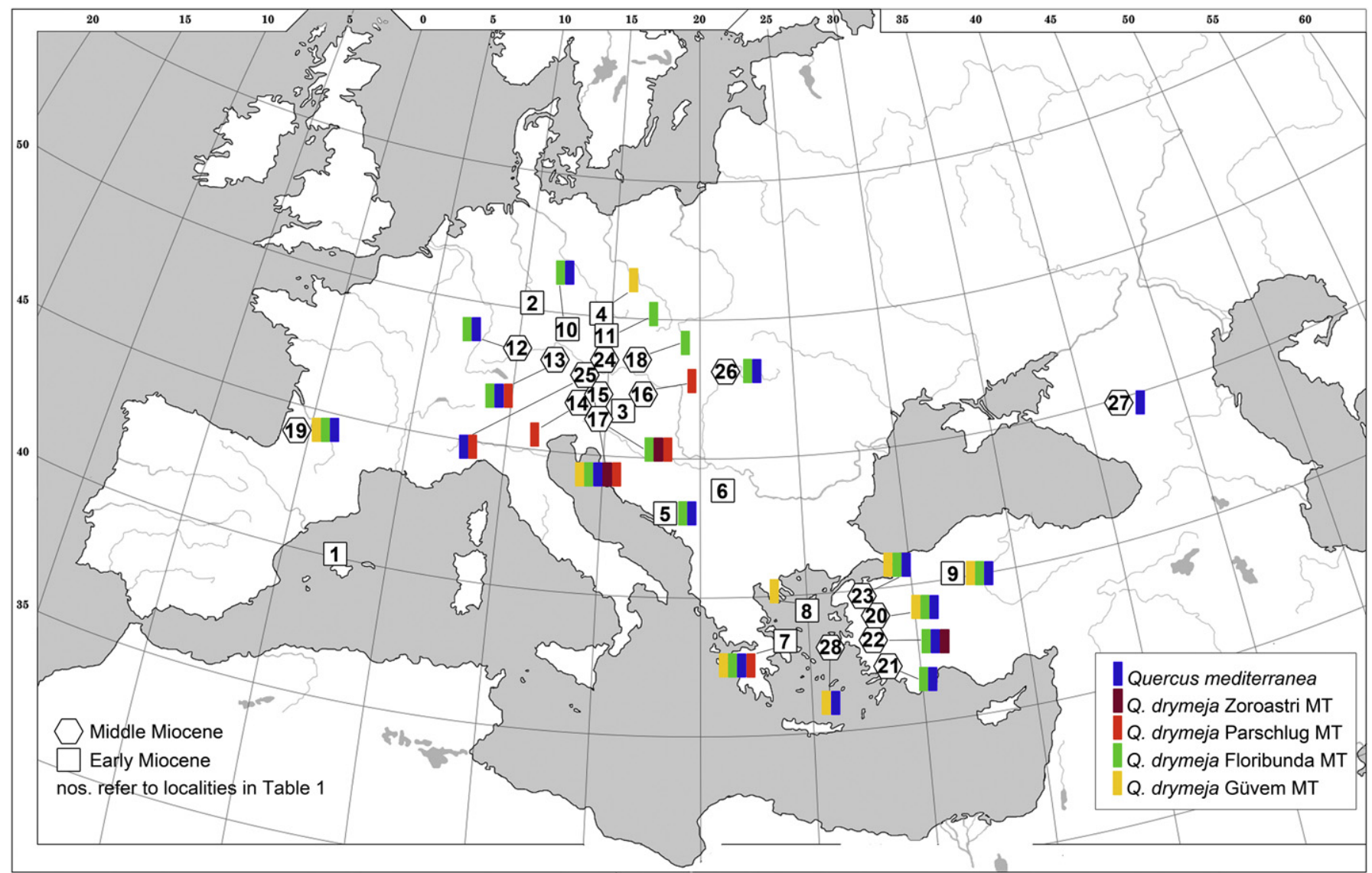

Map 1. Early and middle Miocene records of Quercus drymeja Unger and Q. mediterranea Unger (see also Table SI 1). 


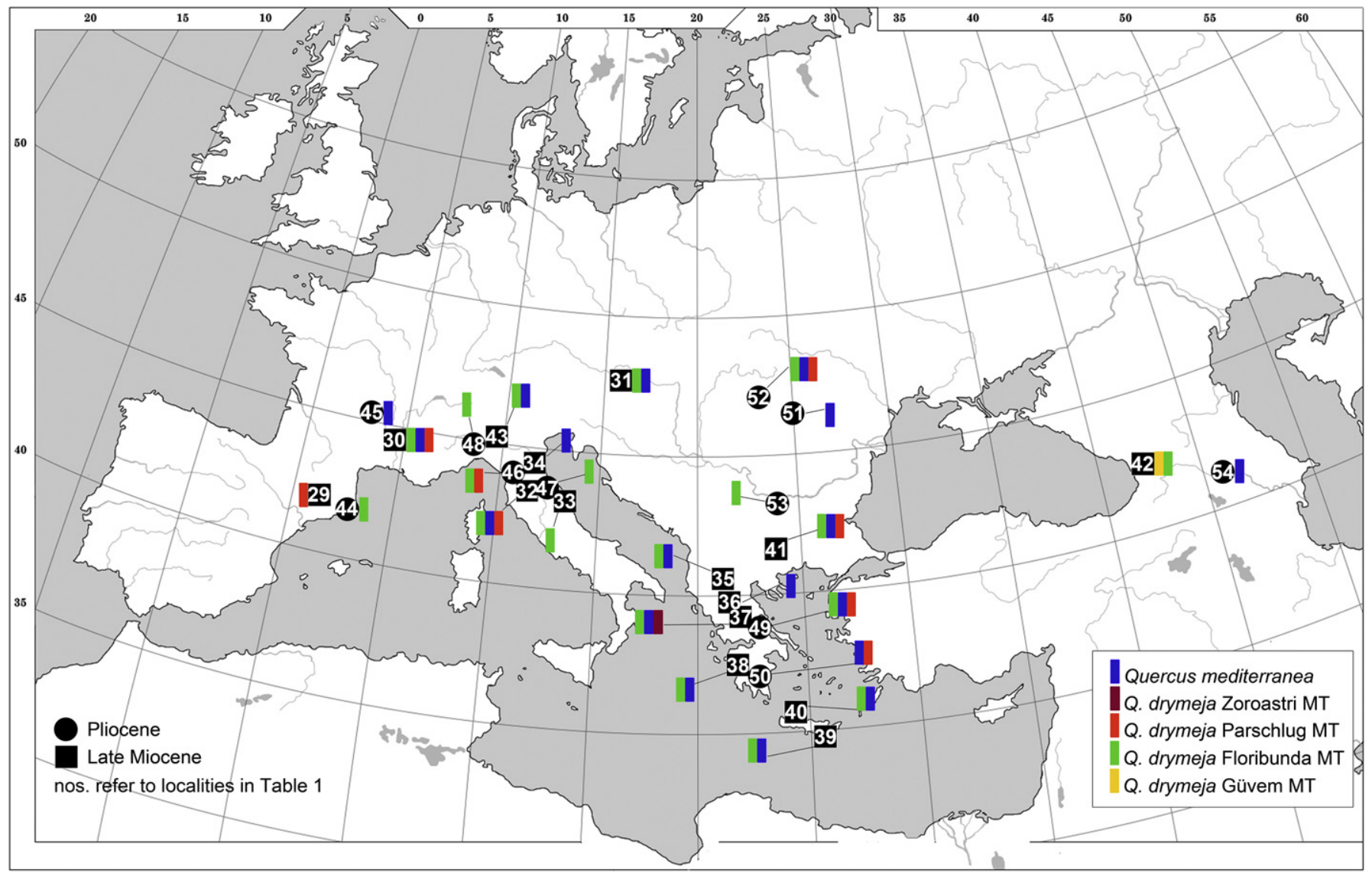

Map 2. Late Miocene and Pliocene records of Quercus drymeja Unger and Q. mediterranea Unger (see also Table SI 1).

\section{Material and methods}

The material investigated for this study partly comes from our own field work carried out between 2008 and 2014 (Likoudi, Greece; Soma, Şahınalı, Tınaz, Salihpaşalar, Turkey) or from existing museum/ university and private collections (Parschlug and Lavanttal, Austria; Güvem, Turkey). In addition, a comprehensive review of published accounts was made (Table 1; Maps 1,2).

Plant fossils recovered from middle and upper Miocene deposits of Likoudi, Soma, Şahınalı, Tınaz, and Salihpaşalar are stored at the Swedish Museum of Natural History (S), Stockholm, and the Department of Forestry, Istanbul University (ISTO-F), Bahçeköy. Material from the Austrian Parschlug and Lavanttal localities, middle Miocene, is stored at the Museum of Natural History Vienna (NHM), the palaeontological collection of the University of Vienna (as SU_LAV), the Geological Survey Vienna (GBA), the Universalmuseum Joanneum, Centre of Natural History (LMJ), Graz, and in private collections (collection Andreas Hassler, [SH]). The rich material from lower Miocene deposits of Güvem was collected by Baki Kasapligil during the late 1960s and 1970s and is stored at the University of California, Museum of Paleontology (UCMP), Berkeley.

Dispersed pollen grains were investigated from lower Miocene plant bearing deposits of Kimi (Greece) and Güvem (Turkey), in order to assess the contributions of different infrageneric groups of Quercus to the palynological assemblages of deposits rich in sclerophyllous Quercus foliage. Sedimentary rock was processed following the protocol described in Grímsson et al. (2008) and the same pollen grains were investigated with LM and SEM (single grain method; Zetter, 1989).

Modern species of Quercus were studied in the herbaria at Edinburgh (E; physical herbarium and online herbarium catalogue at http://elmer. rbge.org.uk/bgbase/vherb/bgbasevherb.php) and Paris (P; physical herbarium and online catalogue at https://science.mnhn.fr/institution/ $\mathrm{mnhn} / \mathrm{search} /$ form). Additional information from herbaria was retrieved from the online herbarium catalogue from Kew (http://apps.kew.org/ herbcat/navigator.do) and New York Botanical Garden (http://sweetgum. nybg.org/science/vh/), and from the Oaks of the World website (http:// oaks.of.the.world.free.fr/). Leaf litter of Quercus ilex was collected from a small grove on the foothills of Mount Olympus, above Katerini, Greece.

We also used the eight-gene time-calibrated phylogeny for Quercus of Hubert et al. (2014) to compare inferred biogeographic relationships of the fossil taxa with the estimated dates of infrageneric splits based on molecular data.

\section{Results}

\subsection{Leaf morphology and taxonomic relationships of Quercus drymeja and Q. mediterranea}

Quercus drymeja and Q. mediterranea display a wide range of morphological variation in early Miocene to Pliocene deposits across western Eurasia. They may be dominating elements of fossil plant assemblages (e.g. Güvem, Aydın/Şahınalı, Turkey; Kimi, Elasona/ Likoudi, Vegora, Greece; Miljevina, Bosnia; Toscana, Italy; Lavanttal, Austria; Kodor, Georgia) or rare accessory elements at other localities (Table 1). In the following, a number of distinct morphotypes are described (Table 2) and compared to particular modern species in a phylogenetic context. The term 'morphotype' as used here refers to "any distinct, more or less stable morphological form of a given organism" (Lincoln et al., 1998).

\subsection{Quercus drymeja Unger}

Published records included within Quercus drymeja are listed under the morphotypes described below. For a complete list of records included within Q. drymeja, see Table SI 1. 
Table 1

Occurrences of Quercus drymeja [D] and Q. mediterranea $[\mathrm{M}]$ in the Neogene of western Eurasia. Numbers indicate position of localities on Maps 1 and 2 .

\begin{tabular}{|c|c|c|c|c|c|c|c|}
\hline & Age & State, locality & Reference & & Xon & Frequency & Remarks \\
\hline 1 & Early Miocene & Spain, Mallorca & $\begin{array}{l}\text { Depape, } 1928 \text {; Arènes and } \\
\text { Depape, } 1956\end{array}$ & $\mathrm{D}$ & & Rare & One leaf fragment \\
\hline 2 & Early Miocene & $\begin{array}{l}\text { Germany, } \\
\text { Kaltennordheim } \\
\text { (Escheri Formation) }\end{array}$ & Mai, 2007 & $\mathrm{D}$ & & Rare & Not figured \\
\hline 3 & Early Miocene & $\begin{array}{l}\text { Austria, } \\
\text { Münzenberg/Leoben }\end{array}$ & von Ettingshausen, 1888 & $\mathrm{D}$ & M & Rare & $\begin{array}{l}\text { As Q. drymeja Unger, Q. lonchitis Unger (D), Q. palaeo-Ilex Ettingshausen } \\
\text { (M) }\end{array}$ \\
\hline 4 & Early Miocene & $\begin{array}{l}\text { Czech Republic, } \\
\text { Cypris Shale }^{\mathrm{a}}\end{array}$ & Bůžek et al., 1996 & $\mathrm{D}$ & & Rare & As Q. cf. drymeja (D) \\
\hline 5 & Early Miocene & Bosnia, Miljevina & Kvaček et al., 1993 & $\mathrm{D}$ & M & Abundant & As Q. ex gr. drymeja (D), Q. mediterranea Unger (M) \\
\hline 6 & Early Miocene & Serbia, Žagubica Basin & Lazarević and Milivojević, 2010 & $\mathrm{D}$ & & Rare & Leaf fragment \\
\hline 7 & Early Miocene & Greece, Kimi, Aliveri & $\begin{array}{l}\text { Unger, 1867; Velitzelos et al., } \\
2014\end{array}$ & $\mathrm{D}$ & M & Abundant & As Q. lonchitis (D), Q. mediterranea (M), Q. zoroastri Unger (D) \\
\hline 8 & Early Miocene & Greece, Lemnos & $\begin{array}{l}\text { Berger, 1953b; Velitzelos et al., } \\
2014\end{array}$ & $\mathrm{D}$ & & Rare & As Q. lonchitis (D) \\
\hline 9 & Early Miocene & Turkey, Güvem area & Paicheler and Blanc, 1981 & $\mathrm{D}$ & M & Abundant & As Myrica spp., Q. drymeja (D), Q. mediterranea (M) \\
\hline 10 & $\begin{array}{l}\text { Early/middle } \\
\text { Miocene }\end{array}$ & $\begin{array}{l}\text { Germany, } \\
\text { Wackersdorf }^{\mathrm{a}}\end{array}$ & $\begin{array}{l}\text { Knobloch and Kvaček, 1976; } \\
\text { Kovar-Eder et al., } 2001\end{array}$ & $\mathrm{D}$ & M & Rare & As Quercus sp. (?D), Q. mediterranea vel Castanea sp. (M) \\
\hline 11 & $\begin{array}{l}\text { Early/middle } \\
\text { Miocene }\end{array}$ & $\begin{array}{l}\text { Czech Republic, } \\
\text { Mydlovary } \\
\text { Formation }^{\mathrm{a}}\end{array}$ & Knobloch and Kvaček, 1996 & $\mathrm{D}$ & & Rare & As Q. cf. drymeja (D) \\
\hline 12 & $\begin{array}{l}\text { Middle Miocene } \\
\text { (Badenian) }\end{array}$ & Germany, Steinheim & Schweigert, 1993 & D & M & Abundant & As Q. drymeja (D), Q. mediterranea (M) \\
\hline 13 & $\begin{array}{l}\text { Middle Miocene } \\
\text { (Badenian) }\end{array}$ & $\begin{array}{l}\text { Germany, } \\
\text { Entrischenbrunn }\end{array}$ & Schmitt and Butzmann, 1997 & $\mathrm{D}$ & M & Rare & As cf. Quercus sp. (M), Myrica sp. (D) \\
\hline 14 & $\begin{array}{l}\text { Middle Miocene } \\
\text { (Badenian) }\end{array}$ & Austria, Lintsching & Ströbitzer, 1999 & $\mathrm{D}$ & & Rare & As $Q$. drymeja (D) \\
\hline 15 & $\begin{array}{l}\text { Middle Miocene } \\
\text { (Badenian) }\end{array}$ & Austria, Parschlug & $\begin{array}{l}\text { Unger, } 1847,1850,1852 \\
\text { Kovar-Eder et al., } 2004\end{array}$ & D & M & Abundant & $\begin{array}{l}\text { As Quercus drymeja, Q. zoroastri (D), Q. urophylla Unger (D), ?Q. gmelini } \\
\text { A.Braun (D), Q. mediterranea (M) }\end{array}$ \\
\hline 16 & $\begin{array}{l}\text { Middle Miocene } \\
\text { (Badenian) }\end{array}$ & Austria, Weingraben & $\begin{array}{l}\text { Berger, 1952a; Draxler and } \\
\text { Zetter, 1991; Jechorek and } \\
\text { Kovar-Eder, } 2004\end{array}$ & $\mathrm{D}$ & & Rare & As $Q$. drymeja $(\mathrm{D})$ \\
\hline 17 & $\begin{array}{l}\text { Middle Miocene } \\
\text { (Badenian) }\end{array}$ & Austria, Lavanttal & Berger, 1955a & $\mathrm{D}$ & M & Abundant & As $\mathrm{Q}$. drymeja (D), Q. mediterranea (M) \\
\hline 18 & $\begin{array}{l}\text { Middle Miocene } \\
\text { (Helvetium) }\end{array}$ & Austria, Teiritzberg & Berger, 1957a & $\mathrm{D}$ & & Rare & As Q. drymeja (D) \\
\hline 19 & $\begin{array}{l}\text { Middle Miocene } \\
\text { (Badenian) }\end{array}$ & France, Arjuzanx ${ }^{\mathrm{a}}$ & Kvaček et al., 2011 & $\mathrm{D}$ & M & Abundant & As Q. drymeja (D), Q. cf. zoroastri, Q. mediterranea (M) \\
\hline 20 & $\begin{array}{l}\text { Middle Miocene } \\
\text { (Badenian) }\end{array}$ & Turkey, Soma & Gemici et al., 1991 & $\mathrm{D}$ & M & Abundant & As Q. drymeja, Q. cf. trojana Webb (D), Q. ilex L., Q. mediterranea (M) \\
\hline 21 & $\begin{array}{l}\text { Middle Miocene } \\
\text { (Badenian) }\end{array}$ & $\begin{array}{l}\text { Turkey, Yatagan } \\
\text { Basin }\end{array}$ & Gemici et al., 1990 & $\mathrm{D}$ & M & Abundant & As Q. drymeja, Q. goeppertii C.O.Weber vel kubinyii (D), Q. ilex (M) \\
\hline 22 & $\begin{array}{l}\text { Middle Miocene } \\
\text { (Badenian) }\end{array}$ & $\begin{array}{l}\text { Turkey, Aydin, } \\
\text { Şahınalı }\end{array}$ & Gemici et al., 1993 & $\mathrm{D}$ & M & Abundant & As Q. drymeja, Castanopsis sp., Q. cf. drymeja (D), Q. mediterranea (M) \\
\hline 23 & $\begin{array}{l}\text { Middle Miocene } \\
\text { (Badenian) }\end{array}$ & Turkey, Balya & Engelhardt, 1903 & $\mathrm{D}$ & M & Abundant & $\begin{array}{l}\text { As Myrica spp., Q. lonchitis, Pterocarya denticulata Weber, } \\
\text { Q. mediterranea, Castanea kubinyii Kováts, Q. drymeja, Q. haidingeri } \\
\text { Ettingshausen (D), Ilex ambigua Unger (M) }\end{array}$ \\
\hline 24 & $\begin{array}{l}\text { Middle Miocene } \\
\text { (Sarmatian) }\end{array}$ & $\begin{array}{l}\text { Austria, } \\
\text { Türkenschanze }\end{array}$ & Berger and Zabusch, 1952 & $\mathrm{D}$ & M & Rare & As $Q$. drymeja (D), Q. mediterranea (M) \\
\hline 25 & $\begin{array}{l}\text { Middle Miocene } \\
\text { (Sarmatian) }\end{array}$ & Austria, Hernals & Berger, 1953a & $\mathrm{D}$ & M & Rare & As Q. drymeja (D), Q. mediterranea (M) \\
\hline 26 & $\begin{array}{l}\text { Middle Miocene } \\
\text { (Sarmatian) }\end{array}$ & Hungary, Erdöbénye & Kováts, 1856; Erdei et al., 2011 & $\mathrm{D}$ & M & Abundant & As Q. szirmayana Kováts (M), Q. pseudoilex Kováts (D), Q. urophylla (D) \\
\hline 27 & $\begin{array}{l}\text { Middle Miocene } \\
\text { (Sarmatian) }\end{array}$ & Russia, Armavir & Kutuzkina, 1964 & & ?M & Rare & As Quercus neriifolia A.Braun (M) \\
\hline 28 & $\begin{array}{l}\text { Middle Miocene } \\
\text { (Sarmatian) }\end{array}$ & $\begin{array}{l}\text { Greece, Chios, } \\
\text { Nenita layers }\end{array}$ & Velitzelos et al., 2014 & & M & Rare & As Q. mediterranea $(\mathrm{M})$ \\
\hline 29 & Late Miocene & Spain, Cerdanya & Barrón, 1999a, 1999b & $\mathrm{D}$ & & Abundant & As Q. drymeja (D) \\
\hline 30 & Late Miocene & France, Ardèche & Boulay, 1887 & $\mathrm{D}$ & M & Abundant & As $Q$. drymeja (D), Q. mediterranea, $Q$. coccifera $(\mathrm{M})$ \\
\hline 31 & $\begin{array}{l}\text { Late Miocene } \\
\text { (Pannonian) }\end{array}$ & $\begin{array}{l}\text { Austria, } \\
\text { Brunn-Vösendorf }\end{array}$ & Berger, 1952b, 1955b & $\mathrm{D}$ & M & Rare & As Quercus cf. drymeja (D), Q. cf. mediterranea (M) \\
\hline 32 & $\begin{array}{l}\text { Late Miocene } \\
\text { (Messinian) }\end{array}$ & $\begin{array}{l}\text { Italy, Tuscany } \\
\text { (Gabbro, Monte } \\
\text { Livornesi) }\end{array}$ & Berger, 1957b & $\mathrm{D}$ & M & Abundant & $\begin{array}{l}\text { As Quercus drymeja, ? Q. goepperti (Weber) Weyland, Q. linguiformis } \\
\text { Boulay (D), Q. mediterranea (M) }\end{array}$ \\
\hline 33 & Late Miocene & Italy, Senigallia & Massalongo and Scarabelli, 1859 & $\mathrm{D}$ & M & Rare & As Juglans italica Massalongo (D) \\
\hline 34 & Late Miocene & $\begin{array}{l}\text { Italy, Borgo } \\
\text { Tossignano }\end{array}$ & Teodoridis et al., 2015 & & M & Rare & As Quercus mediterranea $(\mathrm{M})$ \\
\hline 35 & $\begin{array}{l}\text { Late Miocene } \\
\text { (Pontian) }\end{array}$ & Greece, Vegora $^{a}$ & Kvaček et al., 2002 & $\mathrm{D}$ & M & Abundant & As $\mathrm{Q}$. drymeja (D), Q. mediterranea (M) \\
\hline 36 & Late Miocene & $\begin{array}{l}\text { Greece, Prosilio, } \\
\text { Lava }\end{array}$ & $\begin{array}{l}\text { Knobloch and Velitzelos, } 1986 b ; \\
\text { Kvaček and Walther, } 1989\end{array}$ & & M & Abundant & As Quercus cf. mediterranea \\
\hline 37 & Late Miocene & Greece, Likoudi & Knobloch and Velitzelos, 1986a & $\mathrm{D}$ & M & Abundant & As Q. cf. drymeja (D), Q. cf. mediterranea (M) \\
\hline 38 & Late Miocene & Greece, Platana & Kleinhölter, 1994 & $\mathrm{D}$ & M & Abundant & As $Q$. drymeja (D), Q. mediterranea $(\mathrm{M})$ \\
\hline
\end{tabular}


Table 1 (continued)

\begin{tabular}{|c|c|c|c|c|c|c|c|}
\hline & Age & $\begin{array}{l}\text { State, locality } \\
\text { Formation }\end{array}$ & Reference & \multicolumn{2}{|c|}{$\begin{array}{l}\text { Taxon } \\
(\mathrm{D}, \mathrm{M})\end{array}$} & Frequency & Remarks \\
\hline 39 & Late Miocene & $\begin{array}{l}\text { Formation } \\
\text { Greece, Crete, } \\
\text { Messara Basin }\end{array}$ & Zidianakis et al., 2010 & $\mathrm{D}$ & $\mathrm{M}$ & Rare & As Q. drymeja (D), Q. mediterranea (M) \\
\hline 40 & Late Miocene & $\begin{array}{l}\text { Greece, Crete, } \\
\text { Vrysses Basin }\end{array}$ & Zidianakis et al., 2007 & $\mathrm{D}$ & & Rare & As Q. drymeja (D) \\
\hline 41 & Late Miocene & $\begin{array}{l}\text { Bulgaria, Gotse } \\
\text { Delchev Basin }\end{array}$ & Palamarev and Tsenov, 2004 & $\mathrm{D}$ & $\mathrm{M}$ & $\begin{array}{l}\text { Abundant } \\
\text { (D) }\end{array}$ & $\begin{array}{l}\text { As Q. drymeja, Q. ilex fossilis, Q. lonchitis, Q. sosnowskyi Kolakovsky (D), } \\
\text { Q. mediterranea (M) }\end{array}$ \\
\hline 42 & Late Miocene & Georgia, Kodor & Kolakovsky, 1964 & $\mathrm{D}$ & & Abundant & $\begin{array}{l}\text { As Castanopsis elisabethae Kolakovsky, C. bifurcata Kolakovsky, } \\
\text { C. furcinervis (Rossmässler) Kräusel et Weyland, Q. sosnowskyi f. } \\
\text { angustifolia Kolakovsky (D) }\end{array}$ \\
\hline 43 & $\begin{array}{l}\text { Late } \\
\text { Miocene/Pliocene }\end{array}$ & $\begin{array}{l}\text { Ialy, Montescano, } \\
\text { Lombardia }\end{array}$ & Sordelli, 1896 & $\mathrm{D}$ & $\mathrm{M}$ & Abundant? & $\begin{array}{l}\text { As Q. drymeja (D), Q. gaudinii Lesquereux (D, M), Q. praecursor Saporta } \\
\text { (D) }\end{array}$ \\
\hline 44 & Pliocene & $\begin{array}{l}\text { Spain, Girona, } \\
\text { Caldes de Malavella }\end{array}$ & Robles et al., 2013 & $\mathrm{D}$ & & Rare & As Q. drymeja (D) \\
\hline 45 & Pliocene & $\begin{array}{l}\text { France, Montagne } \\
\text { de Perrier }\end{array}$ & Mai, 1995 & & M & Rare & As Q. mediterranea (M) \\
\hline 46 & Pliocene & Italy, Valdarno & Gaudin and Strozzi, 1859 & $\mathrm{D}$ & M & Abundant & As Quercus drymeja, (? Q. gaudinii) (D), Q. mediterranea (M) \\
\hline 47 & Pliocene & $\begin{array}{l}\text { Italy, Valdarno, } \\
\text { Meleto }\end{array}$ & Fischer and Butzmann, 2000 & $\mathrm{D}$ & & Abundant & As $Q$. drymeja \\
\hline 48 & Pliocene & $\begin{array}{l}\text { Italy, Piedmont, } \\
\text { Valmanera/Asti }\end{array}$ & Martinetto, 2003 & $\mathrm{D}$ & & Rare & As cf. Quercus ilex \\
\hline 49 & Pliocene & Greece, Atalanti & Velitzelos et al., 2014 & $\mathrm{D}$ & M & Abundant & As $\mathrm{Q}$. drymeja (D), Q. mediterranea (M) \\
\hline 50 & Pliocene & Greece, Skoura & Velitzelos et al., 2014 & & M & Rare & As $Q$. mediterranea $(\mathrm{M})$ \\
\hline 51 & Pliocene & Romania, Borsec & Pop, 1936 & & M & Rare & As $Q$. mediterranea, $Q$. cf. ilex \\
\hline 52 & Pliocene & Romania, Chiuzbaia & Givulescu and Ghiurca, 1969 & $\mathrm{D}$ & $\mathrm{M} ?$ & Rare & $\begin{array}{l}\text { As Quercus cf. glaucifolia Andreánszky, Q. drymeja (D), Q. cf. ilex, Q. aff. } \\
\text { coccifera, Q. mediterranea (M) }\end{array}$ \\
\hline 53 & Pliocene (Dacian) & $\begin{array}{l}\text { Bulgaria, Beli Breg } \\
\text { basin }\end{array}$ & Bozukov et al., 2011 & $\mathrm{D}$ & & Rare & As Q. drymeja, Q. sosnowskyi, Q. aff. acrodonta Seemen (D) \\
\hline 54 & Pliocene & $\begin{array}{l}\text { Georgia, Malye } \\
\text { Shiraki }\end{array}$ & Kolakovsky and Ratiani, 1967 & & M & Rare & As Q. mediterranea $(\mathrm{M})$ \\
\hline
\end{tabular}

a Leaf epidermal features preserved.

Leaves petiolate; petiole stout, to $2.5 \mathrm{~cm}$ long; lamina up to $12 \mathrm{~cm}$ long, narrow ovate to lanceolate, broad to narrow elliptical, narrow oblong; base acute to rounded to cordate; apex acute to acuminate, more rarely attenuate; primary vein stout; leaf margin entire or dentate; teeth conspicuous or inconspicuous, occasionally ending in bristle-like spine, basal side straight, sigmoid, or convex, apical side concave; secondary veins regularly or irregularly spaced, departing from primary vein at low to steep angles, occasionally intersecondary veins present, secondary venation camptodromous (usually close to the leaf base), semicraspedodromous, or craspedodromous; tertiary veins mixed opposite/alternate percurrent, more or less perpendicular to secondary veins except for close to the primary vein, where they are bent and inserting the primary vein at right angle, fourth order venation alternate percurrent, areolation well developed, 4-sided to polygonal.

\subsubsection{Quercus drymeja morphotypes (MT)}

3.2.1.1. Quercus drymeja Güvem Morphotype. Plates I (Güvem), Il (Güvem), III, 1-3 (Soma, Parschlug)

1867 Quercus lonchitis Unger - Unger, p. 50, pl. 5, fig. 3

1903 Myrica acuminata Unger - Engelhardt, p. 57, pl. 7, fig. 3 1903 Myrica banksiaefolia Unger - Engelhardt, p. 58, pl. 7, fig. 4 1903 Quercus lonchitis Unger - Engelhardt, p. 58, pl. 7, figs. 6-8 1903 Quercus haidingeri Ettingshausen - Engelhardt, p. 59, pl. 7, fig. 17 1903 Pterocarya denticulata Weber - Engelhardt, p. 63, pl. 7, fig. 9 1903 Myrica acuminata Unger - Engelhardt, pl. 7, fig. 3 ?1953 Quercus lonchitis Unger - Berger, p. 37, figs. 2, 3 1981 Myrica acuminata Unger - Paicheler and Blanc, pl. 3, figs. 7-9 1981 Myrica sp. - Paicheler and Blanc, pl. 3, fig. 10

Table 2

Distinguishing morphological features for Quercus drymeja morphotypes recognized in the present study, and for Quercus mediterranea.

\begin{tabular}{|c|c|c|c|c|c|c|c|}
\hline Taxon & $\begin{array}{l}\text { Lamina } \\
\text { length }\end{array}$ & Lamina shape & Lamina base & $\begin{array}{l}\text { Intersecondary } \\
\text { veins }\end{array}$ & Dentition & Tooth type & $\begin{array}{l}\text { Subsidiary } \\
\text { teeth }\end{array}$ \\
\hline $\begin{array}{l}\text { Quercus drymeja } \\
\text { Güvem } \\
\text { Morphotype (MT) }\end{array}$ & $\begin{array}{l}\text { Up to } \\
10+\mathrm{cm}\end{array}$ & Elliptic to lanceolate & Rounded & Rarely present & $\begin{array}{l}\text { Present along entire margin of } \\
\text { lamina }\end{array}$ & $\begin{array}{l}\text { Inconspicuously } \\
\text { hooked }\end{array}$ & $\begin{array}{l}\text { Occasionally } \\
\text { present }\end{array}$ \\
\hline $\begin{array}{l}\text { Quercus drymeja } \\
\text { Floribunda MT }\end{array}$ & $\begin{array}{l}\text { Up to } \\
10+\mathrm{cm}\end{array}$ & $\begin{array}{l}\text { Narrow oblong to } \\
\text { long narrow ovate, } \\
\text { elliptic }\end{array}$ & Acute to rounded & $\begin{array}{l}\text { Commonly } \\
\text { present }\end{array}$ & $\begin{array}{l}\text { Absent, present along entire } \\
\text { margin, or restricted to upper half } \\
\text { of lamina }\end{array}$ & $\begin{array}{l}\text { Spinose, bristle-like } \\
\text { extension curved } \\
\text { apically }\end{array}$ & $\begin{array}{l}\text { Commonly } \\
\text { present }\end{array}$ \\
\hline $\begin{array}{l}\text { Quercus drymeja } \\
\text { Parschlug MT }\end{array}$ & $\begin{array}{l}\text { Up to } \\
10+\mathrm{cm}\end{array}$ & Lanceolate to elliptic & Acute to cuneate & Rarely present & $\begin{array}{l}\text { Present along entire margin of } \\
\text { lamina }\end{array}$ & Spiny & $\begin{array}{l}\text { Rarely } \\
\text { present }\end{array}$ \\
\hline $\begin{array}{l}\text { Quercus drymeja } \\
\text { Zoroastri MT }\end{array}$ & $\begin{array}{l}\text { Up to } \\
10+\mathrm{cm}\end{array}$ & $\begin{array}{l}\text { Broad elliptic to } \\
\text { ovate/rhombic }\end{array}$ & Acute to rounded & Usually absent & $\begin{array}{l}\text { Present along entire margin, or } \\
\text { restricted to upper half of lamina }\end{array}$ & Coarse & $\begin{array}{l}\text { Rarely } \\
\text { present }\end{array}$ \\
\hline $\begin{array}{l}\text { Quercus } \\
\text { mediterranea }\end{array}$ & $\begin{array}{l}\text { Up to } \\
5+\mathrm{cm}\end{array}$ & $\begin{array}{l}\text { Ovate, elliptic, } \\
\text { oblong, obovate }\end{array}$ & $\begin{array}{l}\text { Acute, rounded, } \\
\text { cordate, inverted } \\
\text { pear-shaped }\end{array}$ & $\begin{array}{l}\text { Occasionally } \\
\text { present }\end{array}$ & $\begin{array}{l}\text { Absent, present along entire } \\
\text { margin, or restricted to upper half } \\
\text { of lamina }\end{array}$ & Coarse or fine & $\begin{array}{l}\text { Present or } \\
\text { absent }\end{array}$ \\
\hline
\end{tabular}




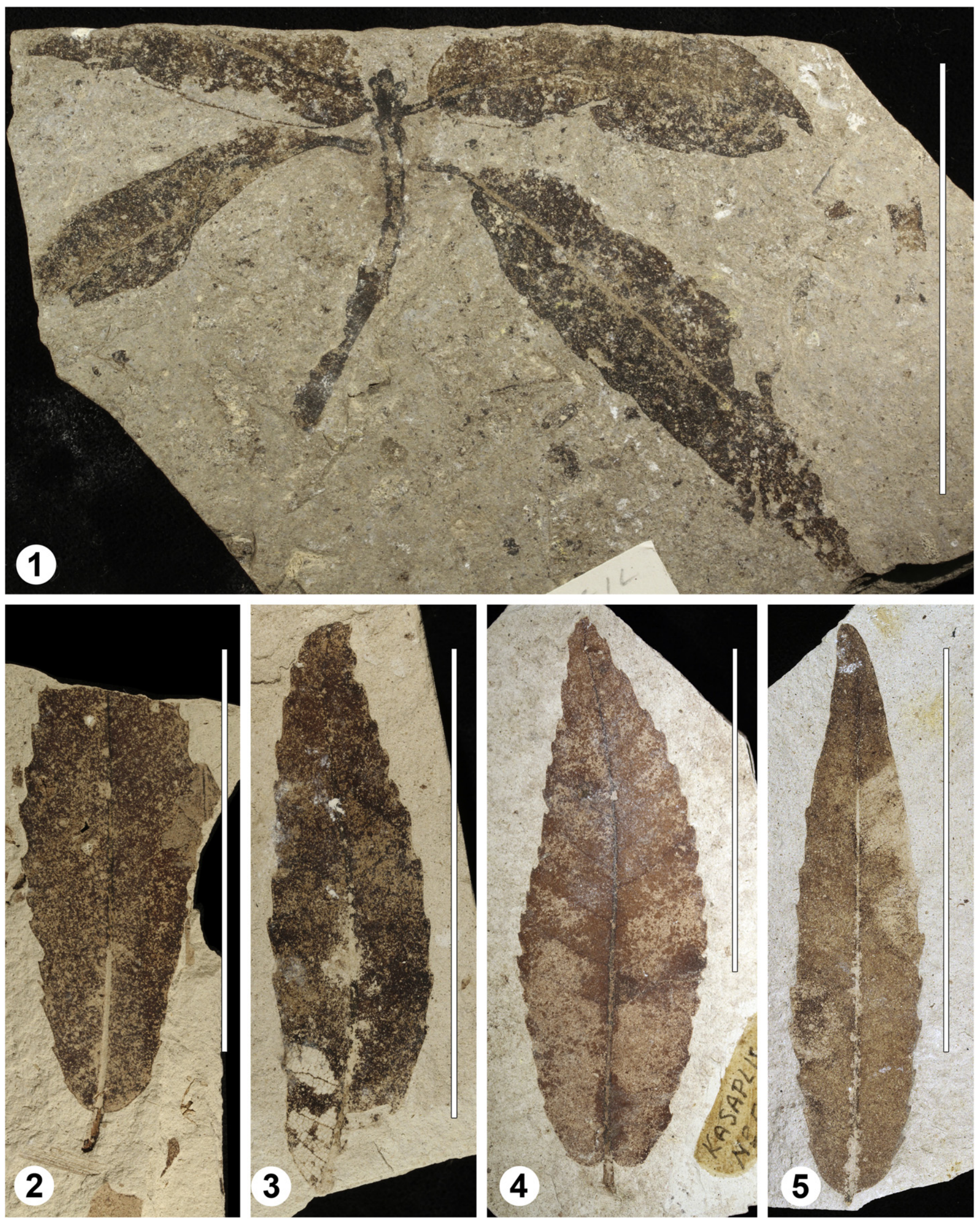

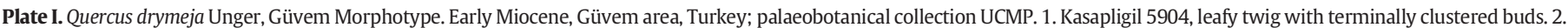
Kasapligil 5812. 3. Kasapligil 5692, typical leaf with regularly dentate margin. 4. Kasapligil 5450. 5. Kasapligil s.n., note elongate acute apex. Scale bar is $5 \mathrm{~cm}$ in $1-5$. 

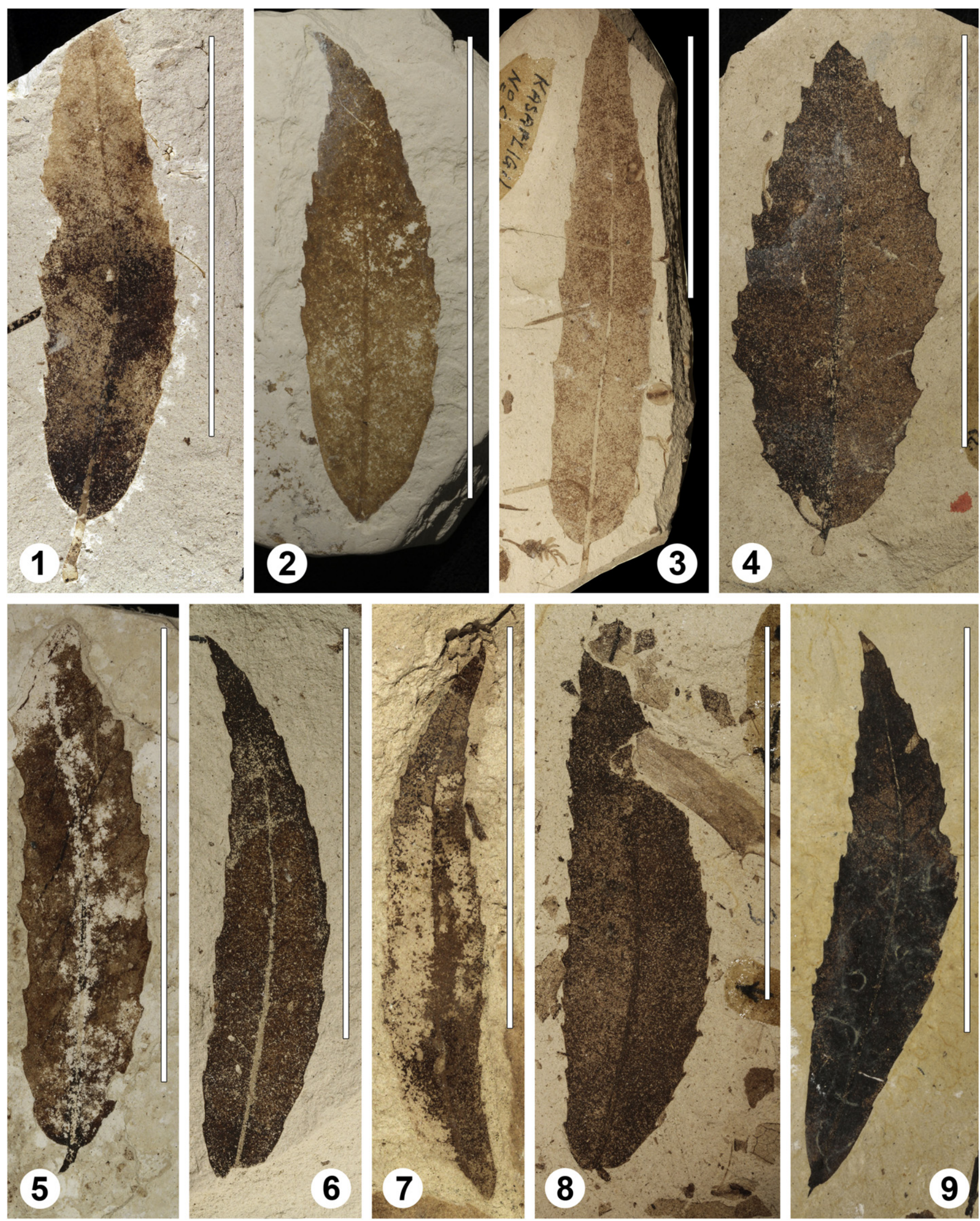

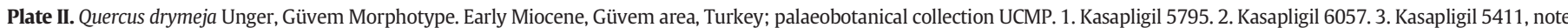

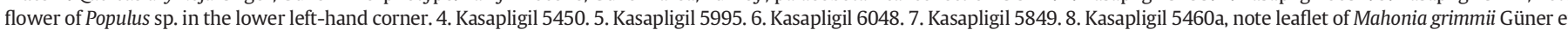
Denk on the right side. 9. Kasapligil 5897, leaf resembling the extinct fagaceous genus Eotrigonobalanus. Scale bar is 5 cm in 1-9. 

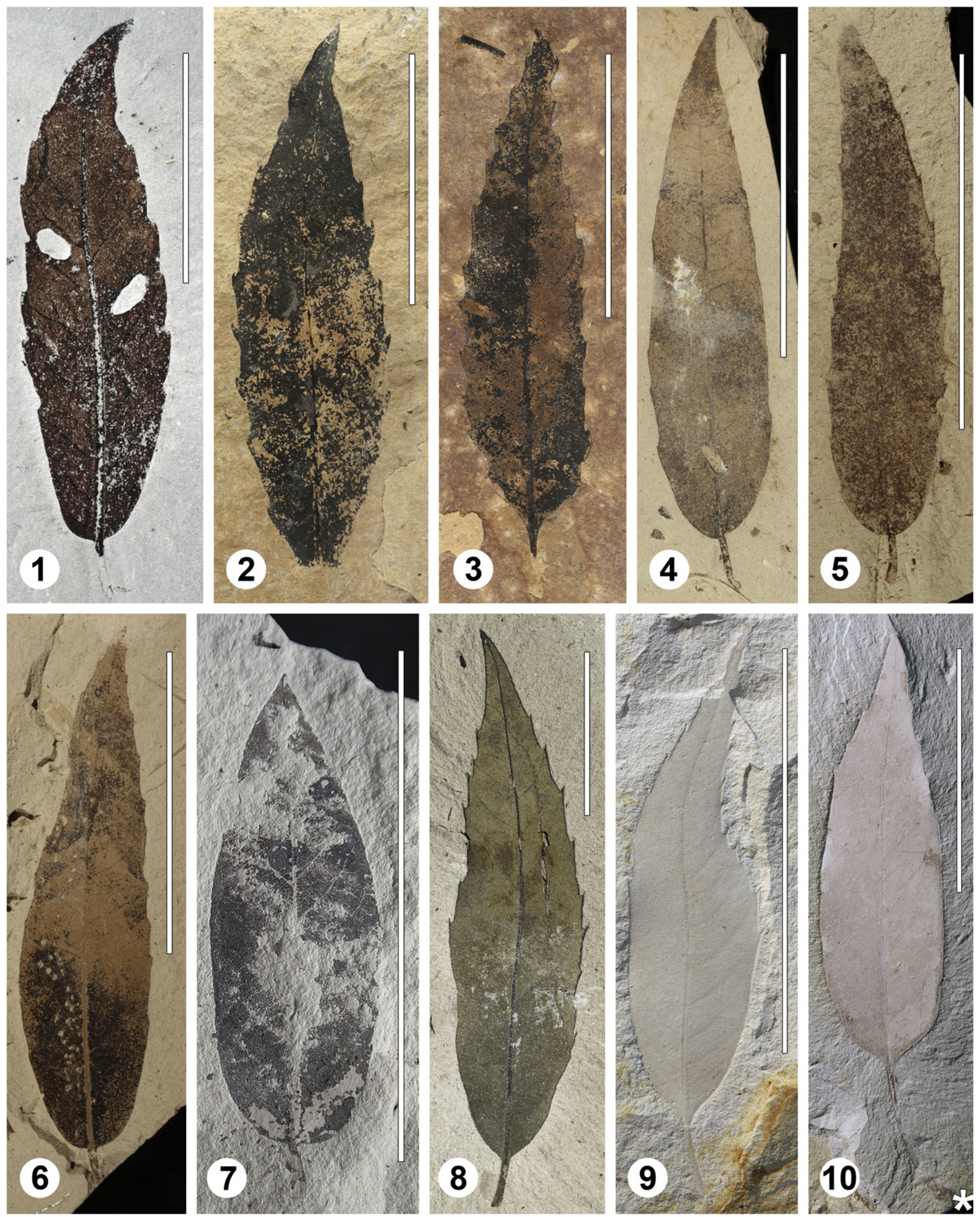

Plate III. Quercus drymeja Unger, Floribunda Morphotype. Early to late Miocene. 1. Soma. 2, 3. Parschlug. 4-6. Güvem. 7. Tinaz. 8. Sahınalı. 9, 10. Likoudi. 1. ISO-F s.n. 2. GBA s.n. 3. GBA s.n. 4. UCMP Kasapligil 5472. 5. UCMP Kasapligil 5902. 6. UCMP Kasapligil 5396. 7. ISTO-F 00548. 8. ISTO-F s.n. 9. S116570. 10. S116701. Asterisk denotes end of long petiole. Scale bar is $5 \mathrm{~cm}$ in $4-7,9,10 ; 3 \mathrm{~cm}$ in $1-3,8$ 
1981 Quercus drymeja Unger - Paicheler and Blanc, pl. 10, figs. 11-14, non pl. 11, figs. 1, 2 (= aff. Eotrigonobalanus furcinervis) 1991 Quercus drymeja Unger - Gemici et al., p. 172, pl. 8, fig. 9 1991 Quercus cf. trojana Webb - Gemici et al., p. 173, pl. 9, fig. 7 2011 Quercus drymeja Unger - Kvaček et al., p. 30, pl. 6, figs. 1-6, pl. 11, figs. 12, 13, pl. 17, figs. 4, 5

Lamina shape narrow elliptic to lanceolate; base rounded to bluntly acute or shallowly cordate; apex acute to elongated acute; margin dentate along entire margin; teeth small, hooked, regular, basal side straight to convex, apical side straight to concave; occasionally subsidiary teeth; secondary veins departing from primary vein at low to steep angles, angle typically increasing towards base.

Remarks: This MT is common in the early Miocene assemblages of the Güvem area (Plates I, II) and occurs sporadically in Kimi (Unger, 1867). It is also found in Soma (Gemici et al., 1991; Plate III, 1), Parschlug (Plate III, 2, 3) and in middle Miocene deposits of Arjuzanx (Kvaček et al., 2011).

Small teeth as in this MT are also seen in leaves of the highly polymorphic species Quercus phillyreoides A.Gray (Quercus Group Ilex), the only member of the group found in Japan, and in leaves of the Mediterranean Q. ilex (e.g. Plate XI, 2). Rounded teeth as present in the specimens from Arjuzanx are also seen in the modern $Q$. kingiana Craib (Group Ilex). Further, this early Miocene foliage of Q. drymeja superficially resembles the extinct Paleogene Fagaceae Castaneophyllum lonchitiforme (Kvaček and Walther, 2012) but differs from these leaf types by straight secondary veins, smaller number of secondary veins, and different leaf base (roundish to bluntly acute versus cuneate to acute). It is noteworthy that among the dispersed pollen grains investigated from the plant-bearing layers in the Güvem area one form appears to represent the extinct Fagaceae Eotrigonobalanus furcinervis (Rossmässler) Walther et Kvaček (Plate SI I, figs. 7-9). Likewise, a few leaves resembling $Q$. drymeja Güvem MT may actually represent Eotrigonobalanus (e.g. Plate II, 9). Similar leaves of Eotrigonobalanus were figured in Velitzelos et al. (2014; pl. 3, figs. 5, 7) from Oligocene layers of eastern Greece.

Modern analogue: Quercus Group Ilex.

3.2.1.2. Quercus drymeja Floribunda Morphotype. Plates III, 4-10, IV, V (Güvem, Likoudi, Salihpaşalar, Soma, Şahınalı, Tınaz), ?VI, 6 (Parschlug) 1856 Quercus urophylla Unger - Kováts, p. 22, pl. 2, fig. 7

1859 Quercus drymeja Unger - Gaudin and Strozzi, p. 44, pl. 4, figs. 2 , $4,6,7,8$

1859 Quercus gaudinii Lesquereux - Gaudin and Strozzi, p. 43, pl. 6, fig. 2 (not 3)

1859 Juglans italica Massalongo - Massalongo and Scarabelli, p. 396,

pl. 33, figs. 2, 13

1867 Quercus zoroastri Unger - Unger, p. 52, pl. 6, fig. 23

1887 Quercus drymeja var. integribasis N.Boulay - Boulay, p. 258

1896 Quercus drymeja Unger - Sordelli, p. 125, pl. 21, figs. 1-4

1896 Quercus praecursor Saporta - Sordelli, p. 127, pl. 20, fig. 11

1896 Quercus gaudinii Lesquereux - Sordelli, p. 128, pl. 20, figs. 8, 10

1903 Quercus mediterranea Unger - Engelhardt, p. 59, pl. 7, fig. 10

1903 Castanea kubinyi Kováts - Engelhardt, p. 60, pl. 7, figs. 12, 15

1903 Quercus drymeja Unger - Engelhardt, p. 59, pl. 7, figs. 13, 14

1952b Quercus cf. drymeja Unger - Berger, p. 92, pl. 1, figs. 48-50

1955a Quercus drymeja Unger - Berger, p. 408, fig. 7

1957a Quercus drymeja Unger - Berger, p. 91, fig. 2

1957b Quercus drymeja Unger - Berger, p. 21, pl. 4, figs. 69, 71

1957b Quercus linguiformis Boulay - Berger, p. 34, pl. 11, fig. 165

1964 Castanopsis elisabethae Kolakovsky - Kolakovsky, p. 79, pl. 24, fig. 5 1964 Castanopsis bifurcata Kolakovsky - Kolakovsky, p. 78, pl. 24, fig. 6 1964 Castanopsis furcinervis (Rossmässler) Kräusel et Weyland -

Kolakovsky, p. 80, pl. 24, figs. 7, 8, pl. 25, figs. 1, 2

1964 Quercus sosnowskyi forma angustifolia Kolakovsky -

Kolakovsky, p. 90, pl. 25, figs. 3-11

1969 Quercus drymeja Unger - Givulescu and Ghiurca, p. 39, pl. 9, fig. 11
1976 Quercus sp. - Knobloch and Kvaček, p. 43, pl. 17, figs. 15, 18, pl.

19, fig. 9, pl. 21, figs. 8, 9

1981 Myrica lignitum (Unger) Saporta - Paicheler and Blanc, pl. 3, fig. 3

1986a, Quercus cf. drymeja Unger “Group 1”, “Group 2” - Knobloch

and Velitzelos, p. 10, pl. 3, figs. 2-4, 7, 8, 10, pl. 4, figs. 6, pl. 5, figs. 2, 7, 8

?1986a, Quercus dubia Knobloch et Velitzelos - Knobloch and

Velitzelos, p. 11, pl. 3, fig. 1

1990 Quercus goeppertii vel kubinyii - Gemici et al., p. 33

1993 Quercus drymeja Unger - Gemici et al., p. 99, pl. 6, fig. 1

1993 Quercus cf. drymeja Unger - Gemici et al., p. 99, pl. 7, figs. 1, 3

1993 Castanopsis sp. - Gemici et al., p. 95, pl. 6, fig. 5

1993 Quercus ex gr. drymeja Unger - Kvaček et al., p. 61, text fig. 4a,

b, pl. 2, figs. 4-7, pl. 3, figs. 1-4

1993 Quercus drymeja Unger - Schweigert, p. 66, pl. 2, fig. 5

1994 Quercus drymeja Unger - Kleinhölter, figs. 2, 6

1996 Quercus cf. drymeja Unger - Knobloch and Kvaček, p. 52, pl. 7,

figs. 1, 2, 5, pl. 8, figs. 4, 4a, pl. 9, fig. 7, pl. 15, fig. 9, text figs. 7, 8

1997 cf. Myrica sp. - Schmitt and Butzmann, p. 59, pl. 3, figs. 7, 8

2000 Quercus drymeja Unger - Fischer and Butzmann, p. 45, pl. 11,

figs. 6-11, text-figs. 63-66

2002 Quercus drymeja Unger - Kvaček et al., p. 66, pl. 10, figs. 8, 12,

pl. 11, figs. 1-6, pl. 15, figs. 2, 7, pl. 30, figs. 5-6 (Vegora, Messinian).

2003 Quercus cf. ilex L. - Martinetto, p. 96, pl. 3, fig. 10

2004 Quercus zoroastri Unger - Kovar-Eder et al., p. 62, pl. 5, fig. 2

2004 Quercus sosnowskyi Kolakovsky - Palamarev and Tsenov,

p. 149, pl. 1, fig. 3, pl. 2, fig. 5, pl. 3, figs. 1, 2

2004 Quercus ilex fossilis - Palamarev and Tsenov, p. 149, pl. 1, fig. 6

2004 Quercus drymeja Unger - Palamarev and Tsenov, p. 150, pl. 2,

fig. 3, pl. 3, figs. 3, 4

2007 Quercus sp. - Zidianakis et al., p. 359, figs. 3a, 5q

2010 Quercus drymeja Unger - Zidianakis et al., fig. 20

2011 Quercus aff. acrodonta Seemen - Bozukov et al., p. 8, pl. 2, figs. 1, 2

2011 Quercus drymeja Unger - Bozukov et al., p. 8, pl. 2, fig. 4

2011 Quercus sosnowskyi Kolakovsky - Bozukov et al., p. 9, pl. 2, figs. 5, 6

2013 Quercus drymeja Unger - Robles et al., p. 79, pl. 1, figs. 14, 15

2014 Quercus drymeja Unger - Velitzelos et al., pl. 28, figs. 9, 10, pl.

29, figs. 1,2

Lamina shape narrow lanceolate, oblong, narrow to broad elliptic; base acute to rounded, symmetrical or \pm asymmetrical; apex acute to acuminate; margin dentate or nearly entire; teeth regular, inconspicuously spinose with bristle-like extensions pointing towards apex; secondary veins irregularly spaced, simple or branched; intersecondary veins present; secondary veins departing from primary vein at steep to low angles.

Remarks: This MT is the most common among the Quercus drymeja morphotypes.

We included within this MT also leaves that slightly differ by more rigid dentition; similar leaves are commonly found in the East Asian Q. engleriana (e.g. Kolakovsky, 1964, pl. 24-26, as Castanopsis spp.). Modern plants of Quercus engleriana have, in addition, leaves with inconspicuously spinose leaf margin (Plate XIV, 4-8), as typical for this MT.

The distinct leaf morphology of this MT links it to four modern species of Quercus Group Ilex, Q. floribunda Wallich ex Lindley (junior syn. Q. dilatata Royle) from the Himalayan region (eastern Afghanistan to western Nepal; Plates XIII, XIV, 1), Q. setulosa Hickel et A.Camus (southern China, Laos, Thailand, Vietnam, Plate XIV, 2, 3), Q. tarokoensis Hayata (Taiwan), Q. spinosa subsp. miyabei (Hayata) A.Camus (syn. Q. tatakaensis Tomiya; Taiwan) and Q. engleriana Seemen (Assam, Tibet, southern China; Plate XIV, 4-6). Some leaves considered by Unger (1867) to belong to Q. zoroastri clearly fall within this MT while those figured by Unger (1852) and the neotype of this taxon selected by Kovar-Eder et al. (2004) do not (see below 3.2.1.4.).

Modern analogues: Quercus floribunda (syn. Q. dilatata), Q. setulosa, Q. tarokoensis, Q. spinosa subsp. miyabei (syn. Q. tatakaensis), and Q. engleriana. 

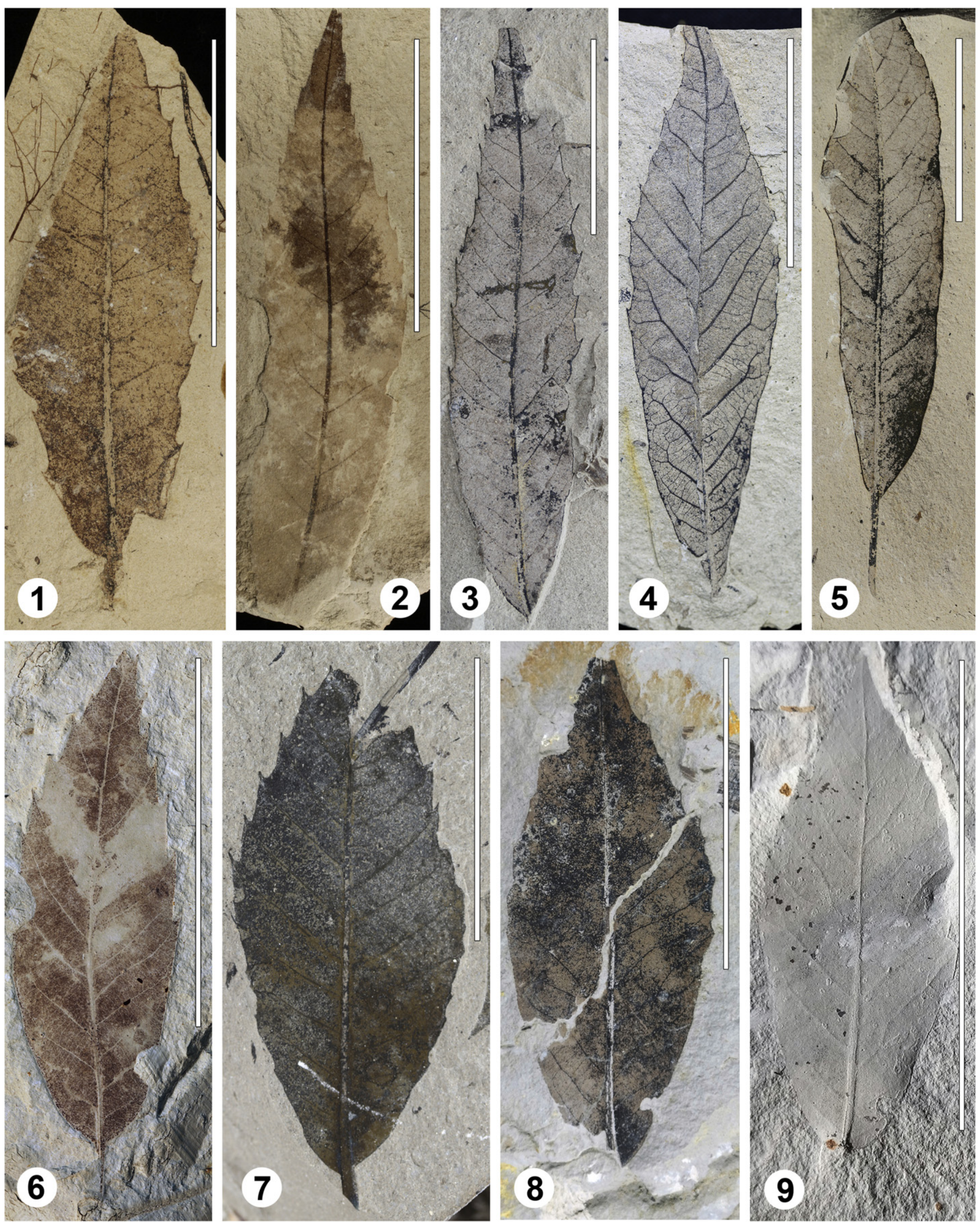

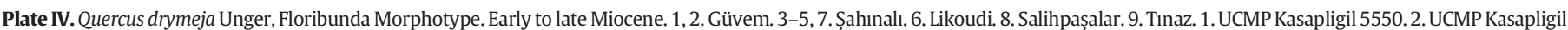
s.n. 3-5. ISTO-F s.n. 6. S116569. 7. ISTO-F s.n. 8. ISTO-F 01520. 9. ISTO-F 01239. Scale bar is $5 \mathrm{~cm}$ in 1, 2, 6, 8, 9; 3cm in 3-5, 7. 

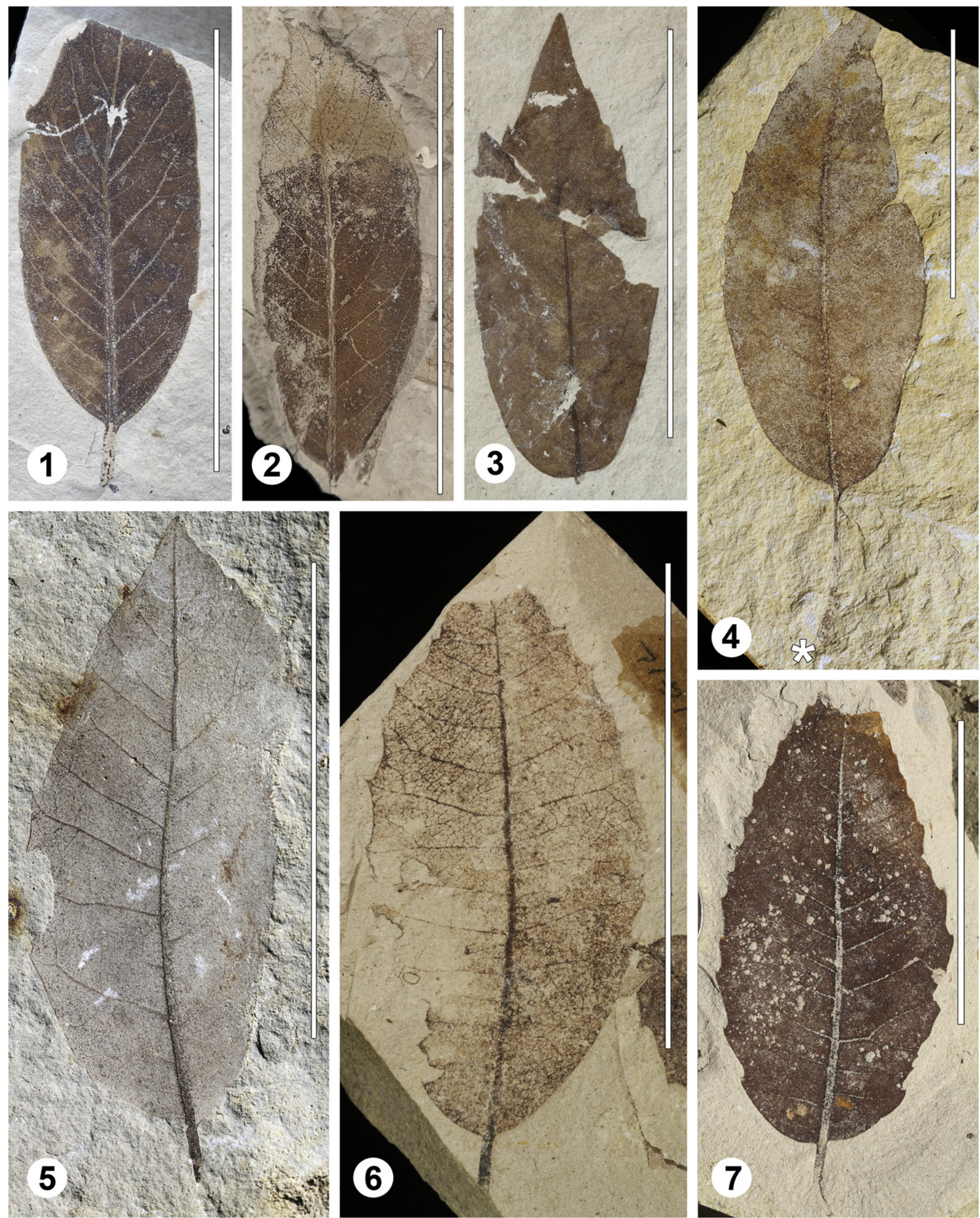

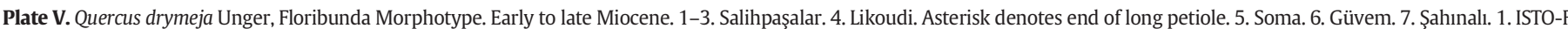
01866. 2. ISTO-F 01856. 3. ISTO-F 01494. 4. S116575. 5. ISTO-F s.n. 6. UCMP Kasapligil 5879. 7. ISTO-F s.n. Scale bar is $5 \mathrm{~cm}$ in $1-7$. 

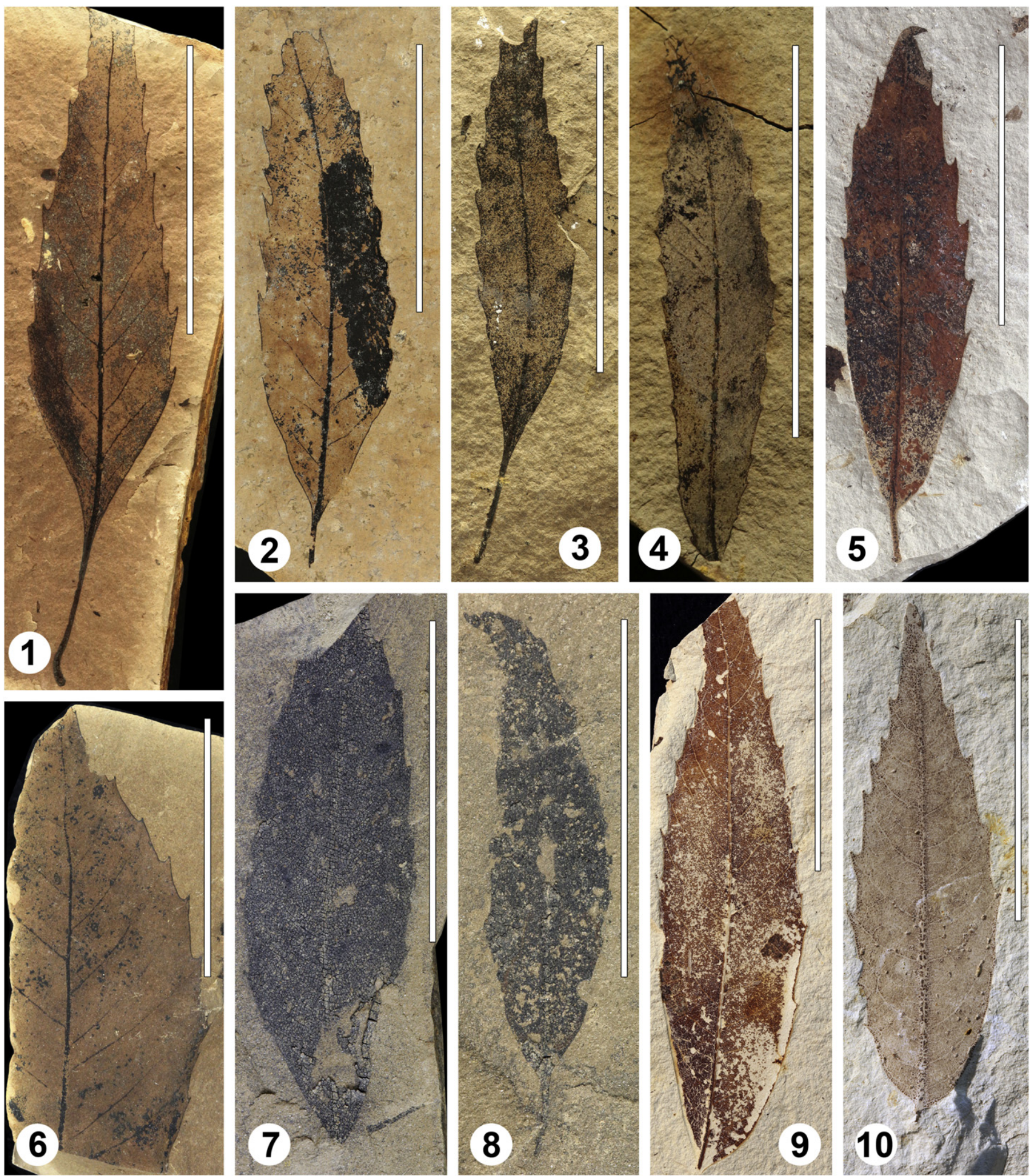

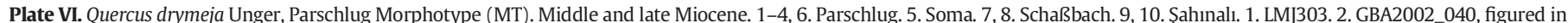
Kovar-Eder et al. (2004, pl. 4, fig. 4). 3. LMJ s.n. 4. NHM 9390. 5. ISTO_F s.n. 6. S133952, Floribunda MT. 7. SH073. 8. SH077. 9. S116564. 10. S116573. Scale bar is 3 cm in 1-10.

3.2.1.3. Quercus drymeja Parschlug Morphotype. Plate VI (Parschlug, Soma, Schaßbach, Likoudi)

1847 Quercus drymeja Unger - Unger, p. 113, pl. 32, figs. 1, 2, 4, not fig. 3 1852 Quercus gmelini A.Braun - Unger, p. 36, pl. 18, fig. 10

1859 Quercus drymeja Unger - Gaudin and Strozzi, p. 44, pl. 4, fig. 1
1867 Quercus lonchitis Unger - Unger, p. 50, pl. 5, figs. 1, 2, 4-13, 16, 17 1887 Quercus drymeja Unger var. ungeri - Boulay, p. 258

?1952a Quercus drymeja Unger - Berger, p. 18, figs. 9, 10

1953 Quercus drymeja Unger - Berger, p. 144, fig. 7

1955a Quercus drymeja Unger - Berger, p. 409, figs. 10-12 
1957b Quercus drymeja Unger - Berger, p. 21, pl. 4, figs. 70, 72-74

?1969 Quercus cf. glaucifolia Andreánszky - Givulescu and Ghiurca, p. 35 , pl. 9 , fig. 7

1997 cf. Myrica sp. - Schmitt and Butzmann, p. 59, pl. 4, fig. 2

1999a Myrica drymeja Unger - Barron, fig. 4d

?2002 Quercus drymeja Unger - Kvaček et al., p. 66, pl. 11, fig. 7

2004 Quercus drymeja Unger - Kovar-Eder et al., p. 61, pl. 4, figs. 1-7 ?2004 Quercus lonchitis Unger - Palamarev and Tsenov, p. 150, pl. 1, fig. 4 Lamina shape narrow lanceolate to ovate lanceolate; base markedly cuneate to acute; apex acute to attenuate; margin dentate; teeth regular, spiny; secondary veins departing from primary vein at acute angles.

Remarks: This distinct MT is most typical of the Parschlug plant assemblage (Unger, 1841; Kovar-Eder et al., 2004; Plate VI, 1-4, 6). It is also common in Kimi (Unger, 1867). In Schaßbach (Plate VI, 7, 8), Valdarno (Gaudin and Strozzi, 1859), Soma (Plate VI, 5), and Likoudi (Plate VI, 9, 10) it is only rarely encountered.

Relationships of this MT with modern species are difficult to establish. Except for Quercus Group Ilex, leaf morphological similarities are also with extant species of Group Cyclobalanopsis, particularly with the Himalayan Q. glauca Thunberg in Murray. Secondary veins are, however, different in species of Group Cyclobalanopsis: vein spacing typically decreases towards the apex and secondary veins are more curved than in species of Group Ilex. Aside from this, no pollen of Group Cyclobalanopsis has been recovered from sediments of Kimi, and the characteristic cups with bracts arranged in concentric rings ("cyclecup oaks") are not known from the fossil record of western Eurasia (e.g. Mai, 1995). Among species of Quercus Group Ilex, the Himalayan species Q. lanata Smith in Rees and Q. leucotrichophora A.Camus (incl. Q. incana Roxburgh) are most similar to this MT (Plate XV).

Modern analogue: East Asian (Himalayan to Chinese) members of Quercus Group Ilex.

3.2.1.4. Quercus drymeja Zoroastri Morphotype. Plate VII, 1-6 (Parschlug, Schaßbach, Likoudi)

1852 Quercus zoroastri Unger - Unger, p. 36, pl. 18, figs. 7, 8 not fig. 9 1955a Quercus mediterranea Unger - Berger, p. 408, fig. 8

1986a, Quercus cf. drymeja Unger "Group 2“ - Knobloch and Velitzelos, p. 10, pl. 4, fig. 3

2004 Quercus zoroastri Unger - Kovar-Eder et al., p. 62, pl. 5, figs. 1, 3, 4 ?2011 Quercus cf. zoroastri Unger - Kvaček et al., p. 30, pl. 6, figs. 12, 13 Lamina shape broad elliptic, rhombic, to ovate; with relatively wide base, basal part tapering into an elongate apical part; base bluntly acute, cuneate, to rounded; apex acute to acuminate; margin dentate along upper two thirds of lamina; teeth regular, coarse or spinose, basal side straight, apical side concave; occasionally subsidiary teeth; secondary veins departing from primary vein at acute angles.

Remarks: This MT is rarely found in specimens from Parschlug and Schaßbach. Specimens that match this morphotype are also present in Likoudi (Plate VII, 6). There are several transitions of such leaves to the Floribunda MT and to Quercus mediterranea. For example, the specimen from Parschlug figured in Plate VII, 1 has more bristle-like spinose teeth (Plate VII, 2 and the specimens figured in Unger, 1852) and approaches the Floribunda MT.

Quercus zoroastri was described in 1850 (Unger, 1850) and subsequently figured in various papers (e.g. Unger, 1852, 1867). In our opinion, the specimens figured by Unger (1867) from Kimi better match the Floribunda MT. Kvaček et al. (2011, pl. 6, figs. 12,13) figured two leaves from Arjuzanx as Q. cf. zoroastri. These leaves differ from typical Zoroastri MT by hooked teeth, a comparatively higher number of secondary veins, and small lamina size. Similar dentition as in these latter specimens is sometimes seen in $Q$. phillyreoides. Further, the leaves from Arjuzanx ascribed to $Q$. cf. zoroastri are so similar in dentition to the specimens referred to as Q. mediterranea (Kvaček et al., 2011, plate 6 , figs. 12,13 [as cf. zoroastri], plate 6 , fig. 16 [as mediterranea]) that they might have originated from the same plant. Notably, a few specimens from Parschlug (e.g. Plate VIII, 11) appear to have similar dentition as well.

The morphological affinities of the Zoroastri MT might be the same as for the Floribunda MT. For example, extant Q. engleriana may have slender leaves with entire margin or bristle-like teeth, or broad leaves with coarse teeth (Plate XIV, 4-8). Hence, the Zoroastri MT might represent coarser leaves produced by the same plants as Parschlug and Floribunda MT leaves.

Modern analogue: Quercus Group Ilex or same as for Floribunda MT.

\subsection{Quercus mediterranea Unger}

Plate VII, 7, 8, VIII

1847 Quercus mediterranea Unger - Unger, p. 114, pl. 32, figs. 5-9

1852 Quercus mediterranea Unger - Unger, p. 35, pl. 18, figs. 1-6

1856 Quercus szirmayana Kováts - Kováts, p. 21, pl. 2, figs. 1-5

1867 Quercus mediterranea Unger - Unger, p. 52, pl. 6, figs. 1-22

1887 Quercus mediterranea Unger - Boulay, p. 259

1887 Quercus coccifera L. - Boulay, p. 259

?1896 Quercus gaudinii Lesquereux - Sordelli, p. 128, pl. 20, fig. 9

1903 Ilex ambigua Unger - Engelhardt, p. 63, pl. 7, fig. 19

1936 Quercus mediterranea Unger - Pop, p. 70, pl. 17, fig. 3

1936 Quercus cf. ilex L - Pop, p. 71, pl. 2, fig. 4, pl. 3, fig. 5, pl. 17, figs. 4-7

1953a Quercus mediterranea Unger - Berger, p. 144, fig. 8

1955b Quercus cf. mediterranea Unger - Berger, p. 76, figs. 9-11

1957b Quercus mediterranea Unger - Berger, p. 33, pl. 11, figs. 155-164

1967 Quercus mediterranea Unger - Kolakovsky and Ratiani, pl. 4, figs. 2-4

1969 Quercus mediterranea Unger - Givulescu and Ghiurca, p. 38, pl. 9, fig. 9

?1969 Quercus cf. ilex L. - Givulescu and Ghiurca, p. 38, pl. 17, figs. 13a, b 1976 Quercus mediterranea Unger vel Castanea sp. - Knobloch and Kvaček, p. 42, pl. 21, fig. 7, pl. 30, fig. 10

1981 Quercus mediterranea Unger - Paicheler and Blanc, pl. 9, figs. 4-11 1986a Quercus cf. mediterranea Unger - Knobloch and Velitzelos, p. 11 , pl. 2, fig. 5

1986b Quercus cf. mediterranea Unger - Knobloch and Velitzelos, p. 30 , pl. 14 , figs. 4,11 , pl. 15 , fig. 7

1990 Quercus ilex L. - Gemici et al., p. 33, fig. 3c

1991 Quercus mediterranea Unger - Gemici et al., p. 173, pl. 9, fig. 6 1993 Quercus mediterranea Unger - Gemici et al., p. 99

1993 Quercus mediterranea Unger - Kvaček et al., p. 62, pl. 3, figs.

$5-7$, pl. 8, fig. 4, text figs. $4 \mathrm{c}-\mathrm{g}$

1993 Quercus mediterranea Unger - Schweigert, p. 67, pl. 2, fig. 2

1994 Quercus mediterranea Unger - Kleinhölter, p. 265

1997 cf. Quercus sp. - Schmitt and Butzmann, p. 59, pl. 2, fig. 11

2002 Quercus mediterranea Unger - Kvaček et al., p. 65, pl. 10, figs. 7,

9-11, pl. 31, figs. 1,2

2004 Quercus mediterranea Unger - Kovar-Eder et al., p. 62, pl. 4, figs. 8-16

2004 Quercus mediterranea Unger - Palamarev and Tsenov, p. 149, pl. 1 , fig. 5

2007 Quercus mediterranea Unger - Zidianakis et al., p. 358, figs. 2h-k, 5j 2010 Quercus mediterranea Unger - Zidianakis et al., fig. $2 \mathrm{~m}$ 2011 Quercus mediterranea Unger - Kvaček et al., p. 32, pl. 6, figs. 14-17 2014 Quercus mediterranea Unger - Velitzelos et al., pl. 25, fig. 13

?2014 Quercus aff. mediterranea Unger - Velitzelos et al., pl. 28, fig. 11 2015 Quercus mediterranea Unger - Teodoridis et al., pl. 261, pl. 7, figs. 7-9

Leaves petiolate, petiole stout, $\leq 1 \mathrm{~cm}$ long; lamina up to $6 \mathrm{~cm}$ long, lamina shape ovate, roundish-obovate, elliptical, or inverted pearshaped; base acute to round to cordate; apex acute to acuminate; primary vein stout, becoming slightly thinner towards apex; leaf margin entire or dentate; teeth conspicuous or inconspicuous, occasionally ending in bristle-like spine or almost reduced to spine, basal side 

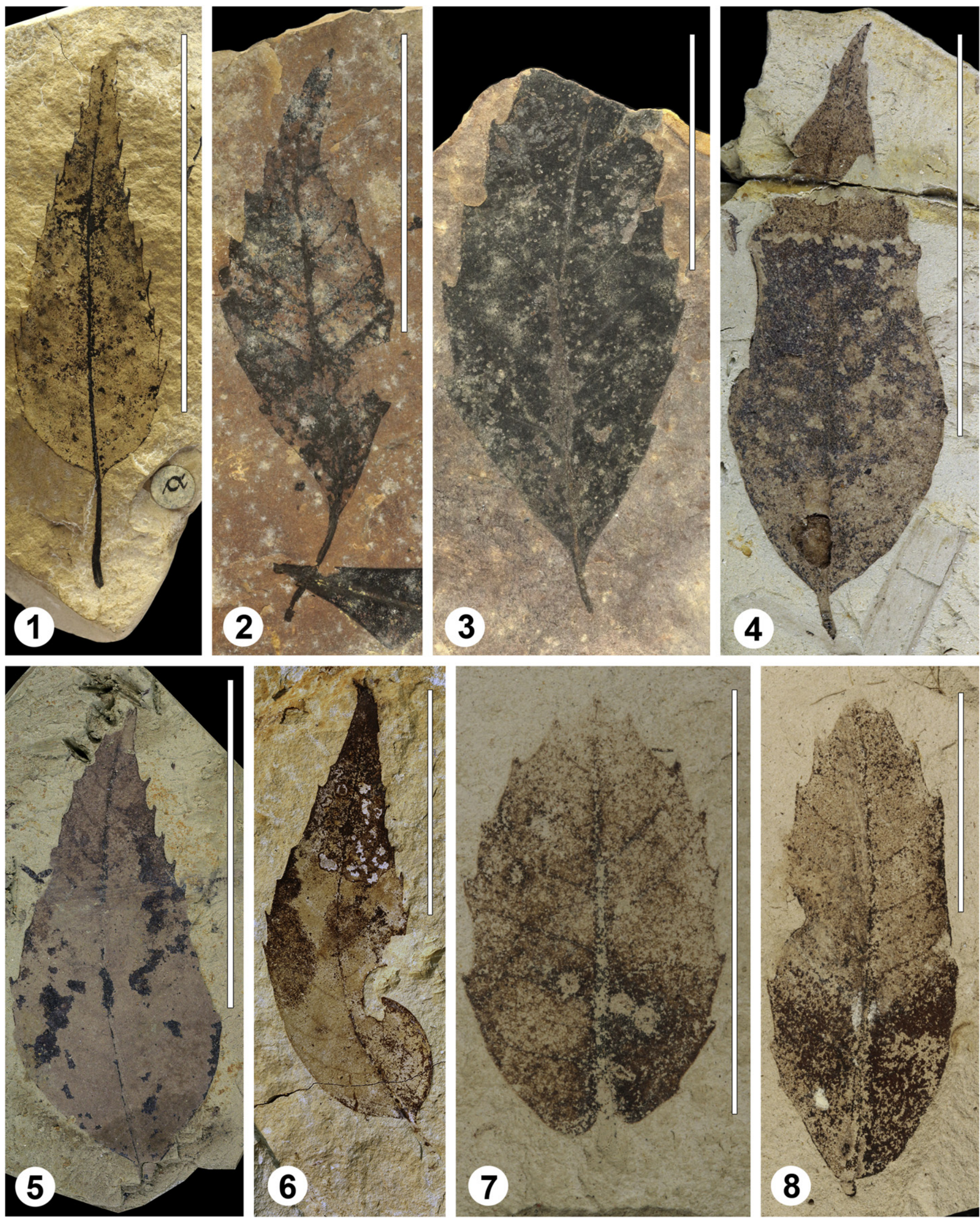

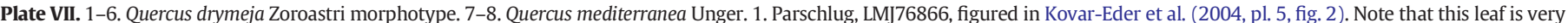

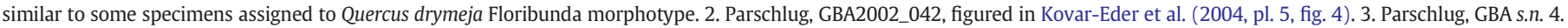

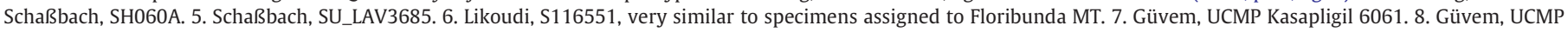
Kasapligil 6076. Scale bar is $5 \mathrm{~cm}$ in 1,$6 ; 3 \mathrm{~cm}$ in $2-5 ; 2 \mathrm{~cm}$ in $7-8$. 
straight, sigmoid, or convex, apical side concave; secondary veins regularly or irregularly spaced, departing from primary vein at low to steep angles, usually vein angle increasing towards base; secondary venation craspedodromous and semicraspedodromous to camptodromous (close to the leaf base), secondary venation camptodromous in entire margined leaves; tertiary veins mixed opposite/alternate percurrent, more or less perpendicular to secondary veins except for close to the primary vein, where they are bent and inserting the primary vein at right angles, fourth order venation alternate percurrent, areolation well developed, 4-sided to polygonal, freely ending ultimate veins unbranched.

Remarks: Specimens of Quercus mediterranea are morphologically fairly stable throughout the Neogene of western Eurasia. Compared to Q. drymeja, the morphological variability among specimens of Q. mediterranea across western Eurasia shows a weaker spatial or temporal pattern. The leaf types encountered in Quercus mediterranea are very similar to those seen in a number of modern species of Quercus Group Ilex (cf. Plate VII, 7, 8, VIII versus Plates IX, XVI, XVII).

Particular leaf types, such as the inverted pear-shaped one (Plate VIII, 1-4, Güvem, Şahınalı, Parschlug, Soma), are encountered in various modern species (e.g. Plate XVI, 6, Q. acrodonta, 7, Q. cocciferoides, 11, $Q$. franchetii). Distinctly spiny leaves as encountered in Salihpaşalar (Plate VIII, 15-17) occur in small leaves of the Himalayan Q. floribunda (Plate XVII, 3, 4). Some specimens of Q. mediterranea (e.g. Unger, 1852 , pl. 18, 1) are markedly similar to modern leaves of $Q$. ilex (Plate IX, 2) and Q. coccifera (Plate XVI, 9).

Modern analogue: Miocene and Pliocene, Quercus Group Ilex; latest Pliocene (?) and Pleistocene, Q. aucheri, Q. coccifera, and Q. ilex.

\subsection{Quercus Group Ilex: fossil vegetation context}

In Oligocene deposits of western Eurasia, the sclerophyllous Quercus Group Ilex is only represented by pollen (Denk et al., 2012). The palynoflora of Cospuden (Germany) reflects lowland swamp forests and well-drained lowland and upland forests in a humid warm temperate climate ( $C f, C w$ climate types according to the Köppen-Geiger climate classification; for explanation of all climate types mentioned in the text see Kottek et al., 2006, and Peel et al., 2007). Genera of Aquifoliaceae, Araliaceae, Arecaceae, Juglandaceae, Mastixioideae, Oleaceae, Rubiaceae, Rutaceae, Sapotaceae, Simaroubaceae, Sterculioideae, Styracaceae, and Symplocaceae, among others, belong to humid warm temperate and subtropical lineages. Ericaceae were diverse (Denk et al., 2012). Oligocene leaf fossils assigned to Quercus Group Ilex from Yunnan, China, were part of broadleaved evergreen forests with dominance of oaks in a "subtropical, warm, wet climate" (Liu et al., 1996). There is, however, no conclusive evidence that these leaf remains indeed belong to Quercus Group Ilex (see below, Section 4.2).

Several localities with abundant sclerophyllous oaks of Quercus Group Ilex are known from the early Miocene of western Eurasia. Kvaček et al. (1993) described an early Miocene leaf assemblage from Bosnia dominated by riparian elements (Glyptostrobus, Alnus, Myrica). Among plants of well-drained soils, Quercus drymeja is the most abundant, followed by Q. mediterranea and Fagus. The latter is an inclusive indicator of fully humid, subtropical or temperate climates with warm or hot summers ( $C f a, C f b, D f b)$. Similarly, the roughly coeval flora of Kimi (Greece) is dominated by riparian Alnus and Myrica with Quercus drymeja and $Q$. mediterranea being most abundant among plants of well-drained soils. Fagus is moderately abundant in the flora of Kimi (Unger, 1867; Velitzelos, 2002). The early Miocene flora of Güvem (Anatolia; this study; T. Denk, unpublished data) is dominated by Quercus drymeja with minor contributions of $Q$. mediterranea and Fagus. Among riparian elements, Acer and Myrica are very abundant (Paicheler and Blanc, 1981). Quercus drymeja and Q. mediterranea are rare or absent in early Miocene assemblages of southern France (Mai, 1995) and on the Greek islands of Lemnos and Lesbos (Velitzelos et al., 2014). These assemblages are possibly representing subtropical lowland stands with palms playing an important role.

Middle Miocene floras containing various amounts of sclerophyllous oaks have been interpreted as representing swamp and riparian forests with Taxodioideae, and humid (Fagus) and subhumid mesophytic forests (sclerophyllous oaks; e.g. Şahınalı, Yatağan Basin, Gemici et al., 1990, 1993; Akgün et al., 2007; Parschlug, Lavanttal, Berger, 1955a; Kovar-Eder et al., 2004). Local expansion of subhumid sclerophyllous forests in the Paratethyan region was attributed to high summer mean temperatures and dry edaphic conditions (Kvaček et al., 2006; see also Rögl, 1999). Late Miocene and early Pliocene plant assemblages with abundant sclerophyllous oaks are commonly also rich in Fagus and have been interpreted as mesophytic forests (Kolakovsky, 1964; Knobloch and Velitzelos, 1986a, 1986b; Fischer and Butzmann, 2000; Kvaček et al., 2002; Velitzelos et al., 2014). Overall, this suggests that sclerophyllous oaks of Quercus Group Ilex occurred in humid subtropical forests during the Oligocene and early Miocene, and in humid temperate forests during the middle and late Miocene and Pliocene.

\subsection{Modern analogues of Quercus drymeja and Q. mediterranea: vegeta- tion context}

Closest morphological similarities of Quercus drymeja were encountered with the modern species Q. floribunda (syn. Q. dilatata), Q. setulosa (incl. Q. laotica), Q. engleriana, Q. tarokoensis, and with Q. lanata and Q. leucotrichophora (all members of Quercus Group Ilex).

These species are mainly distributed south of the Himalayas (Q. floribunda) to China and Southeast Asia ( $Q$. lanata, Q. leucotrichophora). Quercus engleriana is widespread in southwestern China, south-central China and eastern China (Huang et al., 1999; Menitsky, 2005), Q. tarokoensis and Q. spinosa subsp. miyabei (syn. Q. tatakaensis)are endemic species of Taiwan, and Q. setulosa occurs in southern China, Laos, Thailand and Vietnam (Table 4).

Quercus floribunda dominates or forms part of mesophytic forests in regions with sufficient or high amounts of summer precipitation and annual precipitation between 800 and $1200 \mathrm{~mm}$ (Afghanistan; Freitag, 1972) and to $3000 \mathrm{~mm}$ (India, Nepal; Menitsky, 2005). Co-occurring tree species in eastern Afghanistan belong to the genera Pinus, Cedrus, Acer, Celtis, and Juglans; a rich shrub layer comprises species of Viburnum, Syringa, Lonicera, Rhamnus, and others (Supplementary Information, Table SI 2). In northern India (Kangra) and Nepal, Quercus floribunda occurs in the montane vegetation belt, between ca. 1500 and $2400 \mathrm{~m}$. Annual precipitation ranges from ca. 1000 to $3000 \mathrm{~mm}$. The climate is a warm temperate summer-wet climate (Cfa, Cwa, $(w b)$. At its lower vertical distribution $Q$. floribunda co-occurs with Q. lanata, large-leaved Rhododendron, Lyonia (Ericaceae), Myrica (Myricaceae), Litsea, Machilus (Lauraceae), Symplocos (Symplocaceae), and Rhus (Anacardiaceae). Higher up, oak-conifer forests comprise Pinus, Cedrus, Abies, Cupressus, and Acer spp., Betula, Lonicera, Myrsine, Olea, Populus, Rhus, and Viburnum (Menitsky, 2005; Schroeder, 1998; Table SI 2).

While Quercus lanata and Q. floribunda may form pure stands or be accessory elements in mixed broadleaved and conifer forests, Q. engleriana is an accessory element in mixed mesophytic forests of China under a fully humid Cfa or summer-wet Cwa climate (Table SI

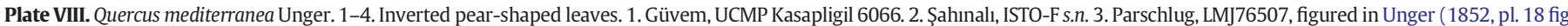

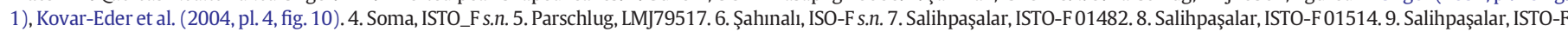

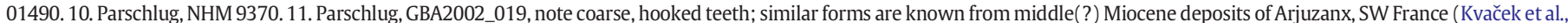

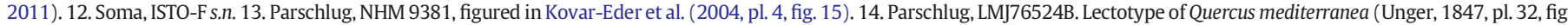
1; Kovar-Eder et al., 2004, pl. 4, fig. 8). 15. Salihpaşalar, ISTO-F 01483. 16. Salihpaşalar, ISTO-F 01481. 17. Salihpaşalar, ISTO-F 01526. Scale bar is 3 cm in 1-6, 8-13; 2 cm in 7, $14-17$. 
3). These forests comprise temperate and a few subtropical elements. Typically, species of Fagus and Cathaya along with diverse Lauraceae are found. Overall, these forests share a number of taxa with Oligocene western Eurasian forests with Quercus Group Ilex (Denk et al., 2012; see above: Cathaya, Ilex, Araliaceae, Ericaceae, Rhododendron, Symplocos, Zanthoxylum) and with early Miocene floras (e.g. diverse Lauraceae).
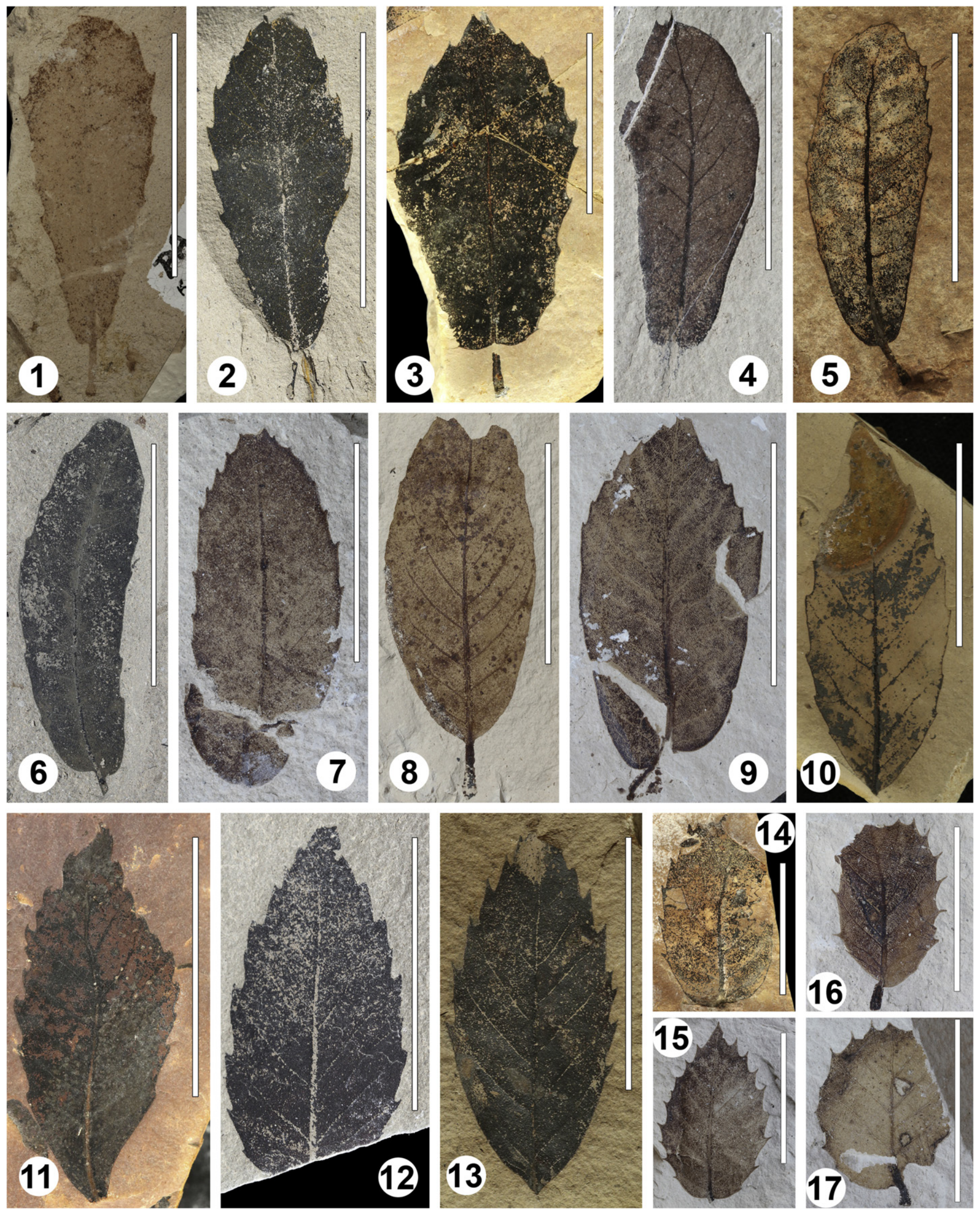
Quercus tarokoensis is part of montane evergreen sclerophyllous forests in eastern Taiwan (Song and Xu, 2003) where it co-occurs with another sclerophyllous oak of Quercus Group Ilex, Q. spinosa David. The climate in this area is distinctly warm temperate and fully humid ( $C f a, C f b$ climates). Similarly, Quercus spinosa subsp. miyabei (syn. Q. tatakaensis Tomiya) forms part of montane laurophyllous forests in eastern and central Taiwan (Yang et al., 2008). Also here, the climate is distinctly temperate $(C f b)$.

Quercus setulosa grows in the montane vegetation belt above tropical monsoon forests. Drier forests including this species are pineoak forests with Poaceae in the understorey. Wet subtropical forests are mixed evergreen-deciduous forests with ferns and epiphytes; they commonly occur along rivers. Oaks co-occur with subtropical tree species of Theaceae, Styracaceae, Magnoliaceae, Myrtaceae, Juglandaceae (Engelhardia), and Rutaceae, and with temperate species of Betulaceae (Carpinus) and Ericaceae (Rhododendron, Vaccinium; Menitsky, 2005; Table SI 4). The predominating climate is a tropical monsoon climate type, $A w$, and a warm temperate monsoon climate type, Cwa.

In addition, a number of modern species that typically produce medium sized to small leaves can specifically be compared with Quercus mediterranea. Among these are the modern Mediterranean species $Q$. coccifera, $Q$. ilex, and $Q$. aucheri (see Plate IX and Plate XVI, 9, for modern leaves closely matching $Q$. mediterranea). Further, a number of Himalayan and East Asian species produce leaves similar to the fossil-species Quercus mediterranea (Plates XVI, XVII). It is, however, noteworthy that in assemblages that contain both Quercus drymeja and $Q$. mediterranea, most leaves assigned to $Q$. mediterranea might represent small leaves of the same plants that produced the leaves of $Q$. drymeja. This suggests that the entities drymeja and mediterranea may in many cases have been produced by the same plants.

\section{Discussion}

4.1. Taxonomic affinity and phylogenetic context of sclerophyllous oaks in the Neogene of western Eurasia

Previous authors have suggested close relationships of $Q$. drymeja with New World representatives of Quercus Group Quercus (white oaks) and Group Lobatae (red oaks; Table 3). Such relationships can be rejected based, firstly, on leaf morphological grounds: extant New World species although resembling $Q$. drymeja display a different range of leaf variability only marginally overlapping with that of Q. drymeja (see below). Further, in the few cases, where leaf cuticles were preserved (e.g. Gotse Delchev Basin, late Miocene, Palamarev and Tsenov, 2004; Vegora, late Miocene, Arjuzanx, middle Miocene, Kvaček et al., 2002, 2011), closest similarities of the leaf epidermis was found with modern species belonging to Quercus Group Ilex (see Deng et al., 2017). Secondly, early Miocene localities with abundant Q. drymeja yield abundant dispersed pollen of Quercus Group Ilex but none of Group Quercus/Lobatae (supplementary information, Plates SI I, SI II). For similar reasons, closer similarities with modern Quercus Group Cyclobalanopsis (cycle cup oaks) as suggested by e.g. Kolakovsky (1964) can be rejected. The characteristic cups of cyclecup oaks have never been found in western Eurasian Cenozoic sediments (Mai, 1995). Also pollen of Quercus Group Cyclobalanopsis has never been encountered in western Eurasia (own observations). Thus, we here consider Q. drymeja and Q. mediterranea to belong to Quercus Group Ilex.

Quercus drymeja and Q. mediterranea have been compared to extant species of five of the six infrageneric groups within Quercus (Table 3). Knobloch and Velitzelos (1986a) compared Q. drymeja with the East Asian Q. serrata Thunberg (Quercus Group Quercus) and Q. setulosa (Group Ilex). Quercus serrata may have narrow elliptical leaves with lobes that approach dentitions (subsp. serrata). However, these leaf shapes are commonly co-occurring with broad-obovate lobed leaves; the lobes typically end in a prominent glandular tip. Quercus serrata belongs to deciduous white oaks (Menitsky, 2005; Denk and Grimm, 2010) that do not possess prominent compound trichome bases. Among North American white oaks, a number of (evergreen) species are somewhat similar to $Q$. drymeja ( $Q$. arizonica Sargent, $Q$. corrugata Hooker, Q. germana Schlechter et Chamisso, Q. tamaiapensis C.H.Muller, and $Q$. vicentensis Trelease). These species differ from $Q$. drymeja by much coarser dentition and generally broader laminas. However, single specimens of $Q$. drymeja are closely similar with these New World white oaks. Based on palynological evidence, also in this case, it appears more likely that these leaves belong to Quercus Group Ilex or Group Cerris and that gross morphological similarities are the result of convergent evolution in leaves of distantly related oak lineages.

Kvaček et al. (2002), although noting that $Q$. mediterranea and Q. drymeja do not differ significantly in leaf epidermal features, suggested the deciduous red oak Q. xalapensis (incl. Q. sartorii; Quercus Group Lobatae) as modern analogue for Q. drymeja. Quercus xalapensis has narrow elliptical to obovate leaves with bristle-like teeth. As in many red oaks, these leaf shapes co-occur with such ones with asymmetrical, broad apical parts of the lamina with prominent teeth (lobes ending in long bristles) never met in $Q$. drymeja leaf assemblages. Similar leaf shapes and patterns of leaf variability are found in several red oaks ( $Q$. depressa Humboldt et Bonpland, $Q$. eduardii Trelease, Q. flocculenta C.H.Muller, Q. galeanensis C.H.Muller, Q. hypoxantha Trelease). These species typically have bristle-like teeth and their range of leaf variability commonly includes lobed leaves. Although a few fossil leaves from Güvem are fairly similar to some of the leaves encountered in these modern species, they are by no means representative. In a later study, Kvaček et al. (2011) suggested $Q$. coccifera as modern analogue for both $Q$. mediterranea and Q. drymeja.

Overall, it is remarkable that Unger's $(1841,1850)$ original concept of $Q$. xalapensis (incl. Q. sartorii) and Q. lancifolia being closely related to $Q$. drymeja has been adopted by many subsequent authors (Table 3). In contrast, only few studies suggested closer relationships with Quercus Group Cyclobalanopsis, the evergreen oaks of the monsoonal parts of tropical and subtropical East Asia. Quercus mediterranea was considered to be more closely related with the modern Q. coccifera by most authors, and this relationship was later supported by leaf epidermal characteristics (Kvaček et al., 2002, 2011). Most of the studies listed in Table 3 compared Q. mediterranea with Mediterranean species of Quercus Group Ilex. A few exceptions are the studies by Sordelli (1896), Paicheler and Blanc (1981), Knobloch and Velitzelos (1986a), and Bozukov et al. (2011), which suggested relationships also with East and Southeast Asian members of Quercus Group Ilex.

Quercus drymeja and Q. mediterranea represent two extremes of a morphological cline, recognized at the inter-specific but also intraspecific level in their potential modern analogues of Quercus Group Ilex (according to Denk and Grimm, 2010; Menitsky, 2005). Long and slender leaves commonly co-occur with small, roundish to elliptical leaves in the same species (e. g. Plates XIII, XIV versus XVII, Q. floribunda, and Plates IX versus X, Q. ilex). A few modern species of Quercus Group Ilex exclusively have small, mediterranea-like, leaves. These are typically found at high elevations from Afghanistan to southwestern China (e.g. Quercus semecarpifolia Smith, Q. guyavifolia Léveillé, Q. rehderiana Handel-Mazzetti, Q. senescens Handel-Mazzetti; Q. monimotricha (Handel-Mazzetti) Handel-Mazzetti) and in the fully Mediterranean species Q. aucheri and Q. coccifera. Based on the modern situation, we have to consider that the two fossil-taxa Quercus drymeja and Q. mediterranea represent different (two or more) biological species in some assemblages, and a single species in others. Aside from this, they clearly fall within the range of the well-circumscribed Quercus Group Ilex (leaf morphology, pollen morphology; Kvaček et al., 2002; Menitsky, 2005; Denk and Grimm, 2009; Denk et al., 2010; Denk and Tekleva, 2014; Deng et al., 2017). 

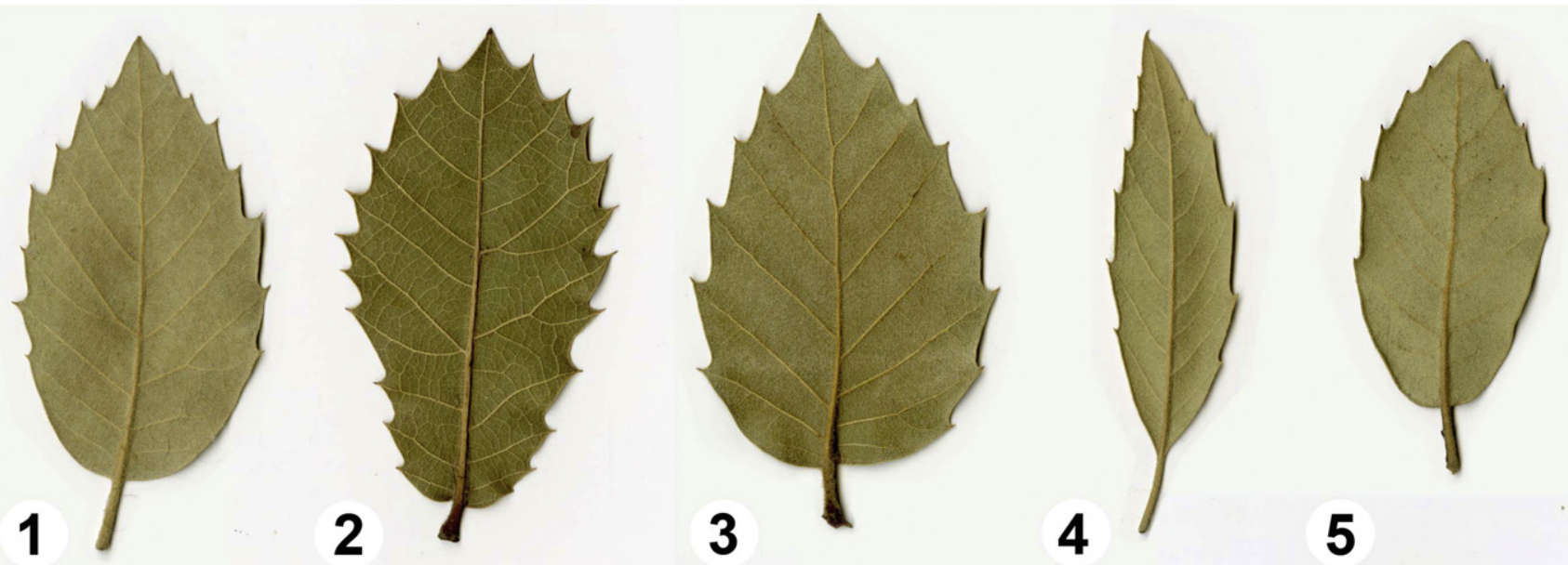

5
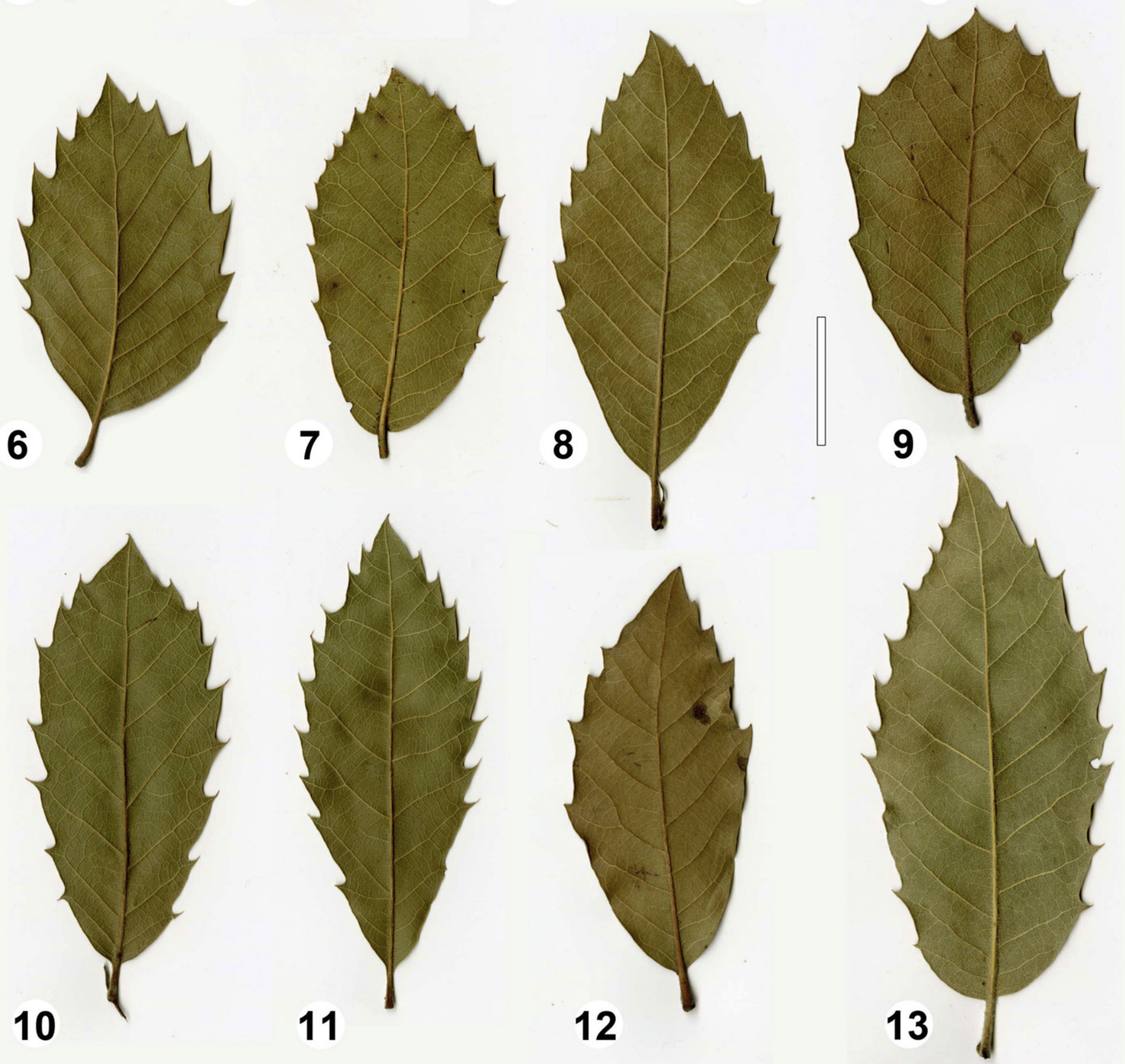

Plate IX. Extant Quercus ilex L. Litter sample, Katerini to Mt. Olympos, above Vrontou, Greece. 1-13. Leaves matching Quercus mediterranea. Scale bar is $2 \mathrm{~cm}$ in 1-13. 
Table 3

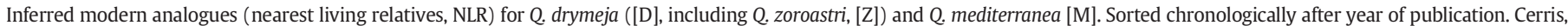
Cyclobalanopsis, Ilex, Lobatae, Quercus refers to infrageneric groups in Quercus recognized in molecular phylogenies and morphology (Denk and Grimm, 2009, 2010).

\begin{tabular}{|c|c|c|c|c|c|c|c|}
\hline Reference & & & NLR Cerris & $\begin{array}{l}\text { NLR } \\
\text { Cyclobalanopsis }\end{array}$ & NLR Ilex & NLR Lobatae (red oaks) & NLR Quercus (white oaks) \\
\hline Unger, 1841, 1850 & $\mathrm{D}$ & M & $\begin{array}{l}\text { Q. persica Jaubert et } \\
\text { Spach }(=Q \text {. brantii } \\
\text { Lindley) (Z), Q. libani } \\
\text { Olivier (D) }\end{array}$ & & $\begin{array}{l}\text { Q. pseudococcifera } \\
\text { Desfontaine }(=\text { Q. coccifera } \\
\text { L.) (M) }\end{array}$ & $\begin{array}{l}\text { Q. calophylla Schlechter et } \\
\text { Chamisso (= Q. candicans Née) } \\
\text { (Z), Q. xalapensis Humboldt et } \\
\text { Bonpland (D) }\end{array}$ & $\begin{array}{l}\text { Q. lancifolia Schlechter et } \\
\text { Chamisso (D) }\end{array}$ \\
\hline Kováts, 1856 & $\mathrm{D}$ & M & & & $\begin{array}{l}\text { Q. alnifolia Poech (M), } \\
\text { Q. ilex L. (D) }\end{array}$ & & \\
\hline $\begin{array}{l}\text { Massalongo and } \\
\text { Scarabelli, } 1859\end{array}$ & $\mathrm{D}$ & M & & & Q. pseudococcifera (M) & Q. xalapensis (D) & \\
\hline Unger, 1867 & $\mathrm{D}$ & M & $\begin{array}{l}\text { Q. persica }(=Q \text {. brantii }) \\
\text { (Z) }\end{array}$ & & Q. pseudococcifera (M) & & Q. lancifolia (D) \\
\hline Sordelli, 1896 & $\mathrm{D}$ & M & Section Cerris (D) & & $\begin{array}{l}\text { Coccifera group (D), Q. ilex } \\
\text { (D, M), Q. phyllireoides A. } \\
\text { Gray (D), section Cerris (D) }\end{array}$ & & \\
\hline Engelhardt, 1903 & $\mathrm{D}$ & $\mathrm{M}$ & & & $\begin{array}{l}\text { Q. ilex }(\mathrm{D}) \text {, } \\
\text { Q. pseudococcifera }(\mathrm{M})\end{array}$ & Q. sartorii Liebmann (D) & Q. lancifolia (D) \\
\hline $\begin{array}{l}\text { Depape, 1928; } \\
\text { Arènes and } \\
\text { Depape, } 1956\end{array}$ & $\mathrm{D}$ & & $\begin{array}{l}\text { Q. chinensis Bunge }(= \\
\text { Q. variabilis Blume) }\end{array}$ & & & Q. sartorii, Q. xalapensis & $\begin{array}{l}\text { Q. serrata Thunberg, } \\
\text { Q. lancifolia }\end{array}$ \\
\hline Pop, 1936 & & M & & & Q. coccifera & & \\
\hline Berger, 1952a & $\mathrm{D}$ & & & $\begin{array}{l}\text { [Q. turbinata Blume } \\
(=Q . \text { gemelliflora } \\
\text { Blume })]\end{array}$ & & & $\begin{array}{l}\text { Berger meant Q. turbinata } \\
\text { Liebmann (= } \\
\text { Q. polymorpha Schlechter } \\
\text { et Chamisso) }\end{array}$ \\
\hline $\begin{array}{l}\text { Berger and Zabusch, } \\
1952\end{array}$ & $\mathrm{D}$ & M & & & Q. ilex (M) & & \\
\hline Berger, 1953a & $\mathrm{D}$ & M & Q. suber L. (M) & & Q. coccifera $(\mathrm{M})$, Q. ilex $(\mathrm{M})$ & & \\
\hline $\begin{array}{l}\text { Berger, 1952b, } \\
\quad 1955 \mathrm{~b}\end{array}$ & $\mathrm{D}$ & M & & & Q. ilex $(\mathrm{M})$ & & \\
\hline Berger, 1955a & $\mathrm{D}$ & $\mathrm{M}$ & & & Q. ilex $(\mathrm{M})$ & Q. xalapensis (D) & $\begin{array}{l}\text { Q. turbinata }(= \\
\text { Q. polymorpha) }(\mathrm{D})\end{array}$ \\
\hline Berger, 1957a & $\mathrm{D}$ & & & & & $\begin{array}{l}\text { "Various evergreen oaks of S North } \\
\text { America" }\end{array}$ & $\begin{array}{l}\text { "Various evergreen oaks of } \\
\text { S North America" }\end{array}$ \\
\hline Berger, 1957b & $\mathrm{D}$ & M & & $\begin{array}{l}\text { Q. turbinata }(= \\
\text { Q. gemelliflora) }(\mathrm{D}) \text {, } \\
\text { Q. glauca Thunberg } \\
\text { (D) }\end{array}$ & Q. ilex (M) & & $\begin{array}{l}\text { Q. lancifolia }(\mathrm{D}) \text {, } \\
\text { Q. corrugata Hooker (D) }\end{array}$ \\
\hline Kutuzkina, 1964 & & $? \mathrm{M}$ & & & & $\begin{array}{l}\text { Q. phellos L. (?M), Q. imbricata } \\
\text { Michaux (?M) }\end{array}$ & \\
\hline Kolakowski, 1964 & $\mathrm{D}$ & & Q. suber & & $\begin{array}{l}\text { Q. alnifolia (refers to } \\
\text { Q. sosnowskyi various } \\
\text { forms but not } \mathrm{f} \text {. } \\
\text { angustifolia), } \mathrm{Q} \text {. ilex }\end{array}$ & & \\
\hline $\begin{array}{l}\text { Kolakovsky and } \\
\text { Ratiani, } 1967\end{array}$ & & M & & & Q. coccifera, $Q$. ilex & & \\
\hline $\begin{array}{l}\text { Givulescu and } \\
\text { Ghiurca, } 1969\end{array}$ & $\mathrm{D}$ & $\mathrm{M} ?$ & & & & & Q. serrata (D) \\
\hline $\begin{array}{l}\text { Paicheler and Blanc, } \\
1981\end{array}$ & $\mathrm{D}$ & M & & $\begin{array}{l}\text { Q. myrsinifolia } \\
\text { Blume (D) }\end{array}$ & $\begin{array}{l}\text { Q. ilex }(\mathrm{M}), \mathrm{Q} \text {. coccifera } \\
\text { (M), Q. floribunda Wallich } \\
\text { (D) }\end{array}$ & & $\begin{array}{l}\text { Q. lancifolia (D), Q. serrata } \\
\text { (D) }\end{array}$ \\
\hline $\begin{array}{l}\text { Knobloch and } \\
\text { Velitzelos, 1986a }\end{array}$ & $\mathrm{D}$ & M & & & $\begin{array}{l}\text { Q. coccifera }(\mathrm{M}), \text { Q. ilex } \\
(\mathrm{M}), \text { Q. setulosa }(\mathrm{D})\end{array}$ & & Q. serrata (D) \\
\hline $\begin{array}{l}\text { Knobloch and } \\
\text { Velitzelos, 1986b; } \\
\text { Kvaček and } \\
\text { Walther, } 1989\end{array}$ & & M & & & Q. coccifera, Q. ilex & & \\
\hline Gemici et al., 1991 & $\mathrm{D}$ & M & $\begin{array}{l}\text { Q. castaneifolia } \\
\text { C.A.Meyer (D) }\end{array}$ & & $\begin{array}{l}\text { Q. coccifera }(\mathrm{M}) \text {, Q. ilex } \\
\text { (M), Q. pseudococcifera } \\
(\mathrm{M})\end{array}$ & Q. sartorii $(\mathrm{D})$ & \\
\hline Gemici et al., 1993 & $\mathrm{D}$ & $\mathrm{M}$ & Q. castaneifolia (D) & & Q. coccifera $(\mathrm{M})$ & Q. sartorii (D) & \\
\hline Bủžek et al., 1996 & $\mathrm{D}$ & & $\begin{array}{l}\text { Q. chinensis }(= \\
\text { Q. variabilis) }\end{array}$ & & & & Q. serrata \\
\hline $\begin{array}{l}\text { Barrón, 1999a, } \\
\text { 1999b }\end{array}$ & $\mathrm{D}$ & & E Asia & E Asia & E Asia & & E Asia \\
\hline Kvaček et al., 2002 & $\mathrm{D}$ & $\mathrm{M}$ & & & Q. coccifera $(\mathrm{M})$ & Q. xalapensis (D) & \\
\hline Kvaček et al., 2011 & $\mathrm{D}$ & $\mathrm{M}$ & & & Q. coccifera $(\mathrm{M}, \mathrm{D})$ & & \\
\hline Bozukov et al., 2011 & $\mathrm{D}$ & & & & Q. acrodonta Seemen & & \\
\hline $\begin{array}{l}\text { Velitzelos et al., } \\
2014\end{array}$ & $\mathrm{D}$ & M & & & Quercus Group Ilex (M, D) & & \\
\hline This study & $\mathrm{D}$ & $\mathrm{M}$ & & & Quercus Group Ilex (M, D) & & \\
\hline
\end{tabular}




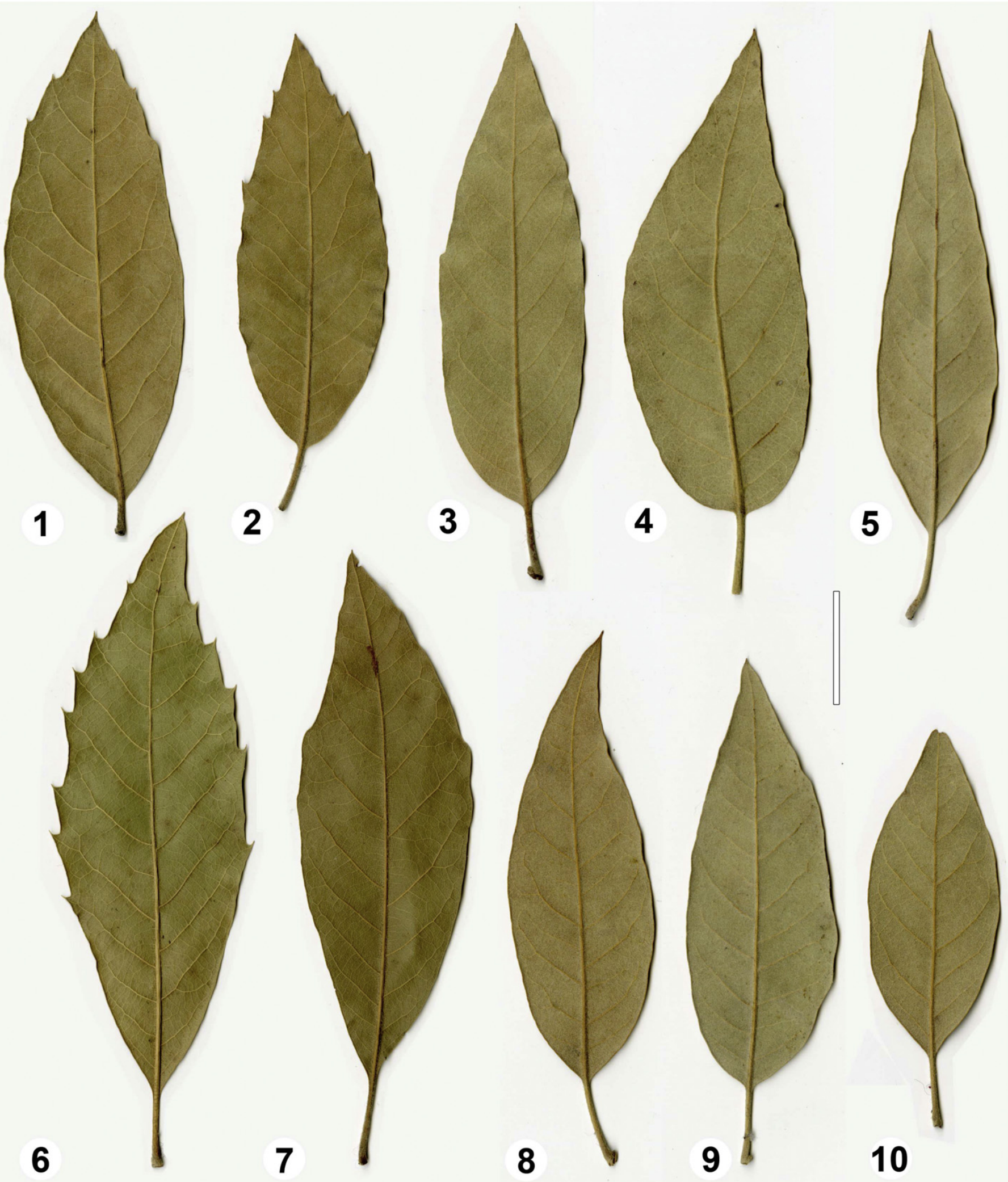



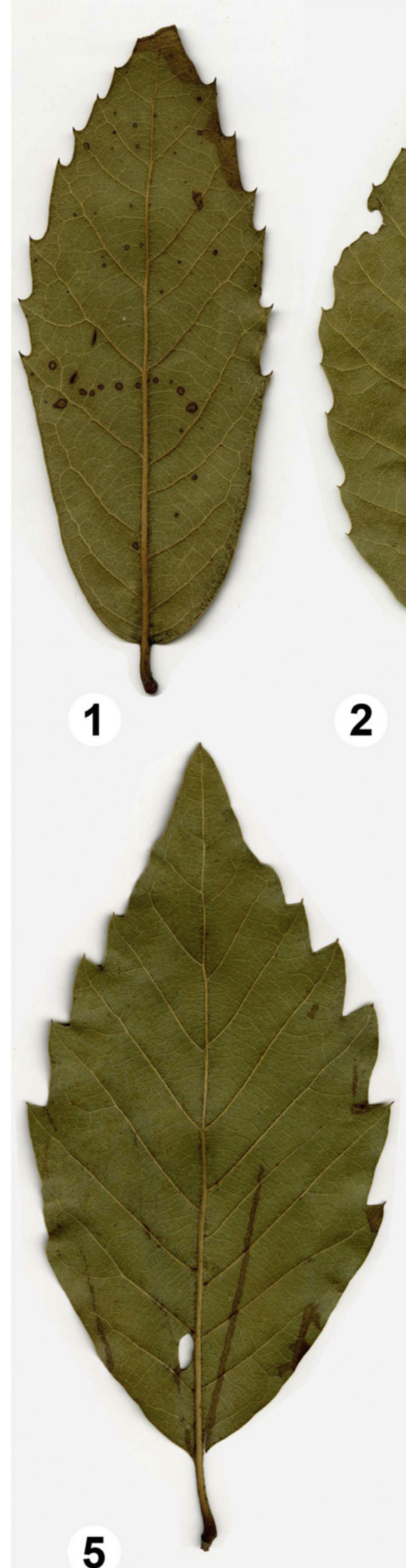

2
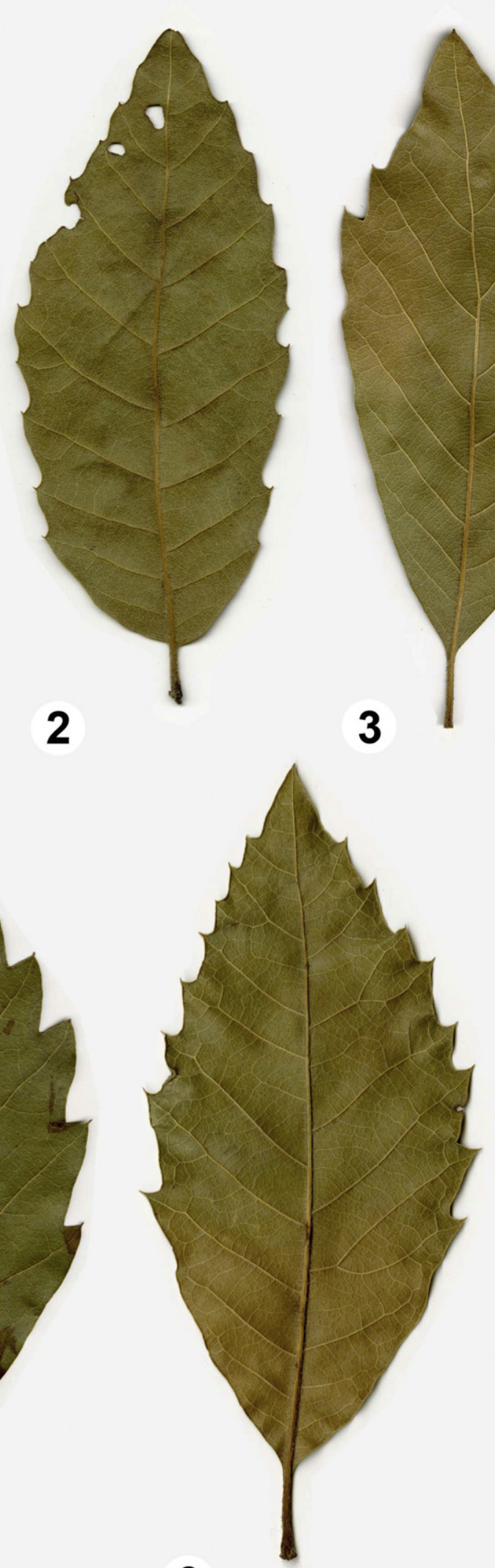

6
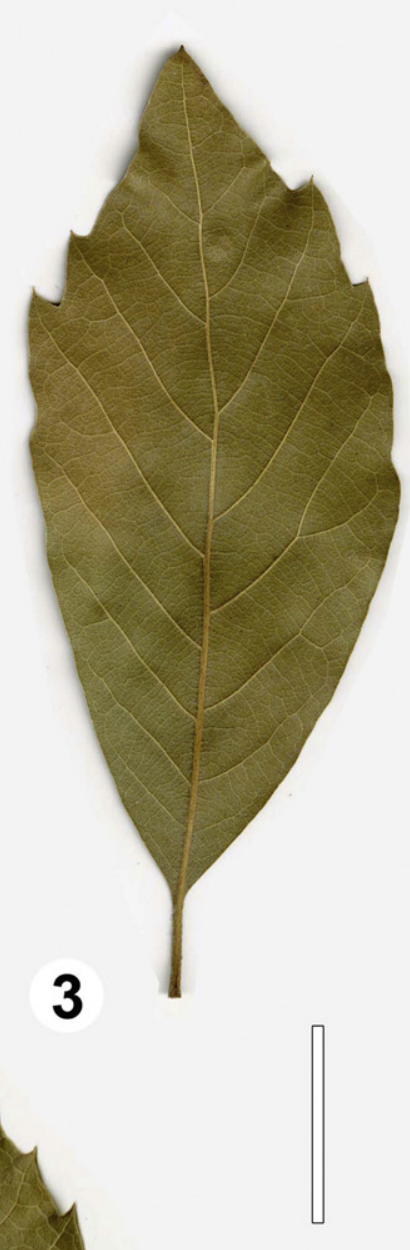

4

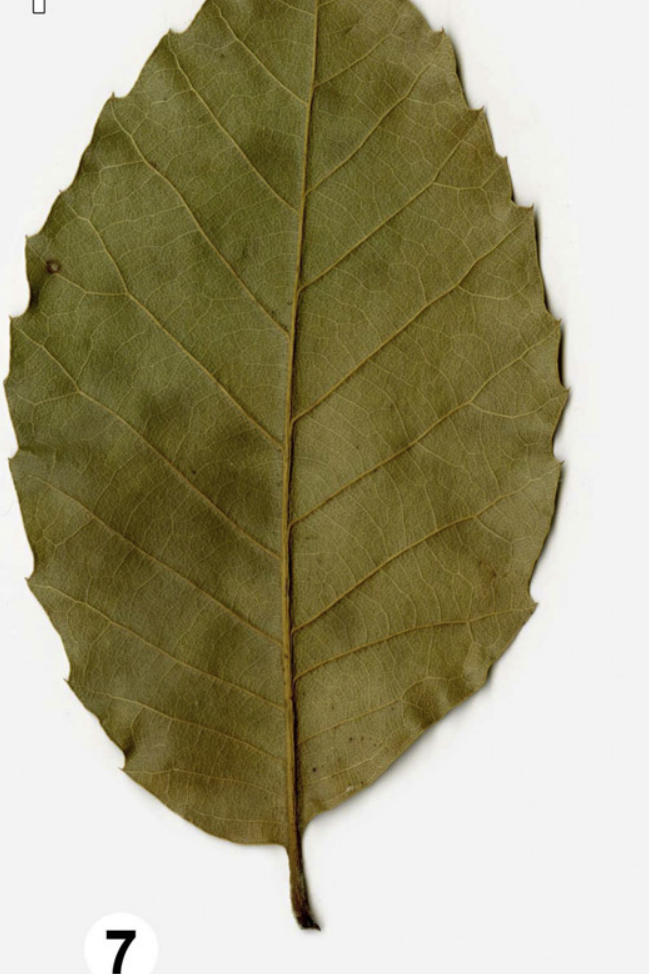

7

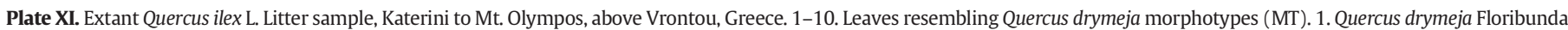
MT. 2. Quercus drymeja Güvem MT. 3-7. Quercus drymeja Zoroastri MT. Scale bar is $2 \mathrm{~cm}$ in 1-7. 


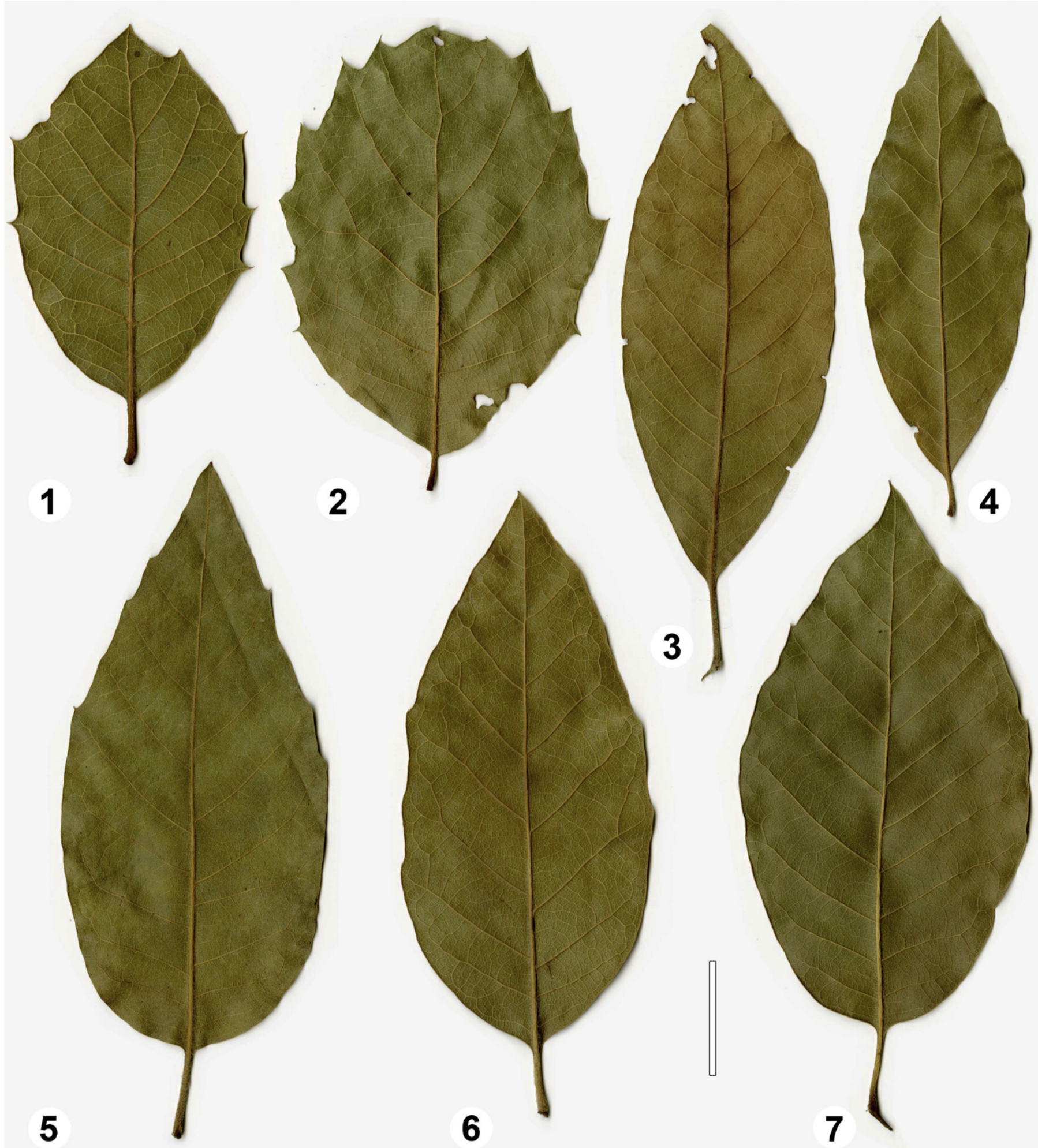



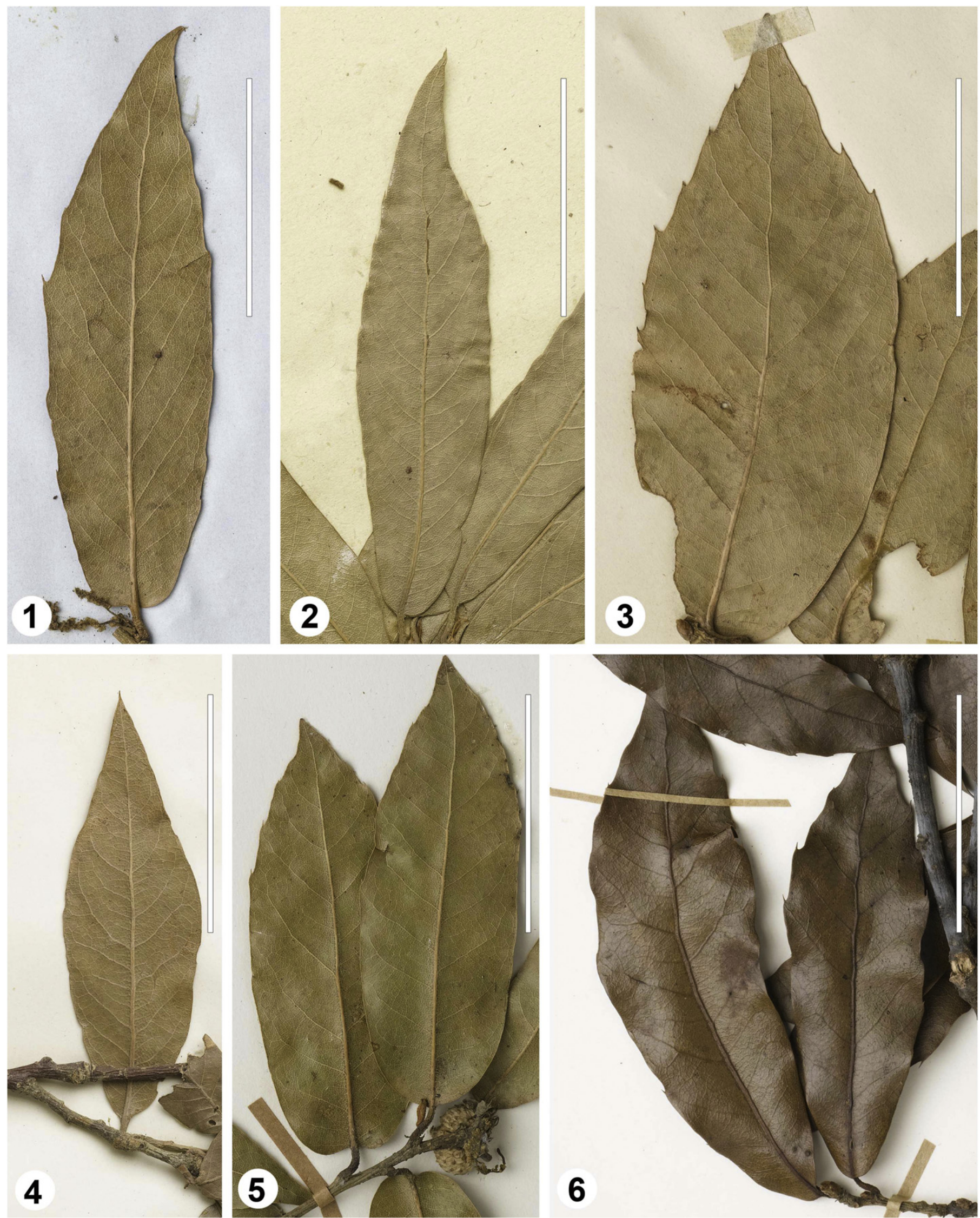

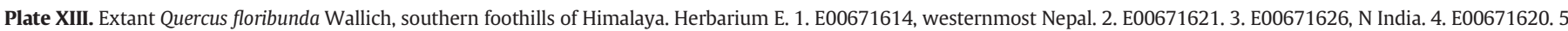
E00451993, W Nepal. 6. E00132049, W Nepal. Scale bar is $5 \mathrm{~cm}$ in 1-6. 

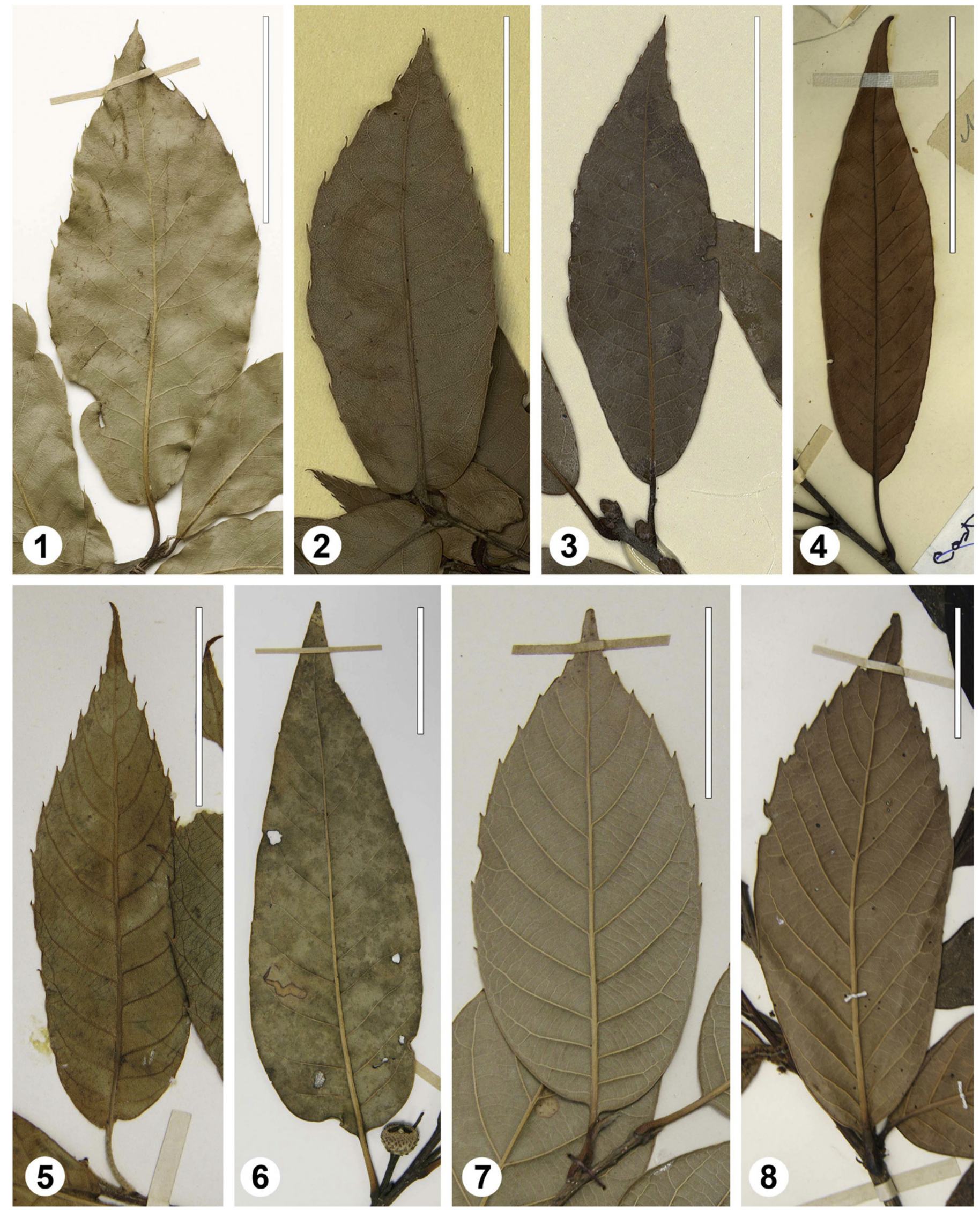

Plate XIV. Extant members of Quercus Group Ilex. 1. Quercus floribunda Wallich. Herbarium E. 2, 3. Quercus setulosa Hickel et A.Camus, Herbarium P. 4-8. Quercus engleriana Seemen, Herbarium E. 1. E00132035, westernmost Nepal. 2, 3. P06813203, Vietnam. 4. E00275658, Guizhou, China. 5. E.H. Wilson 3633, Sichuan, China. 6. Z.-Y. Li et al. 171, Henan, China. 7. W.K. Hu 8864, Sichuan, China. 8. W.P. Fang 948, Sichuan. Scale bar is $3 \mathrm{~cm}$ in 1-8. 
Kvaček et al. (2002, 2011) found that the abaxial leaf epidermis in Q. drymeja from Vegora, Greece, differed from extant $Q$. ilex by its almost hairless abaxial leaf surface, and that leaf epidermal features of $Q$. drymeja and $Q$. mediterranea were fairly similar. Epidermal features of the fossil taxa suggested closer relationship with the Mediterranean
Q. coccifera. Quercus drymeja foliage from Arjuzanx, France, resembling the Güvem MT of the present study also showed leaf epidermal characteristics consistent with the material from Vegora. In a recent investigation, Deng et al. (2017) studied epidermal characteristics of all modern members of Quercus Group Ilex and stated that the fossil-species
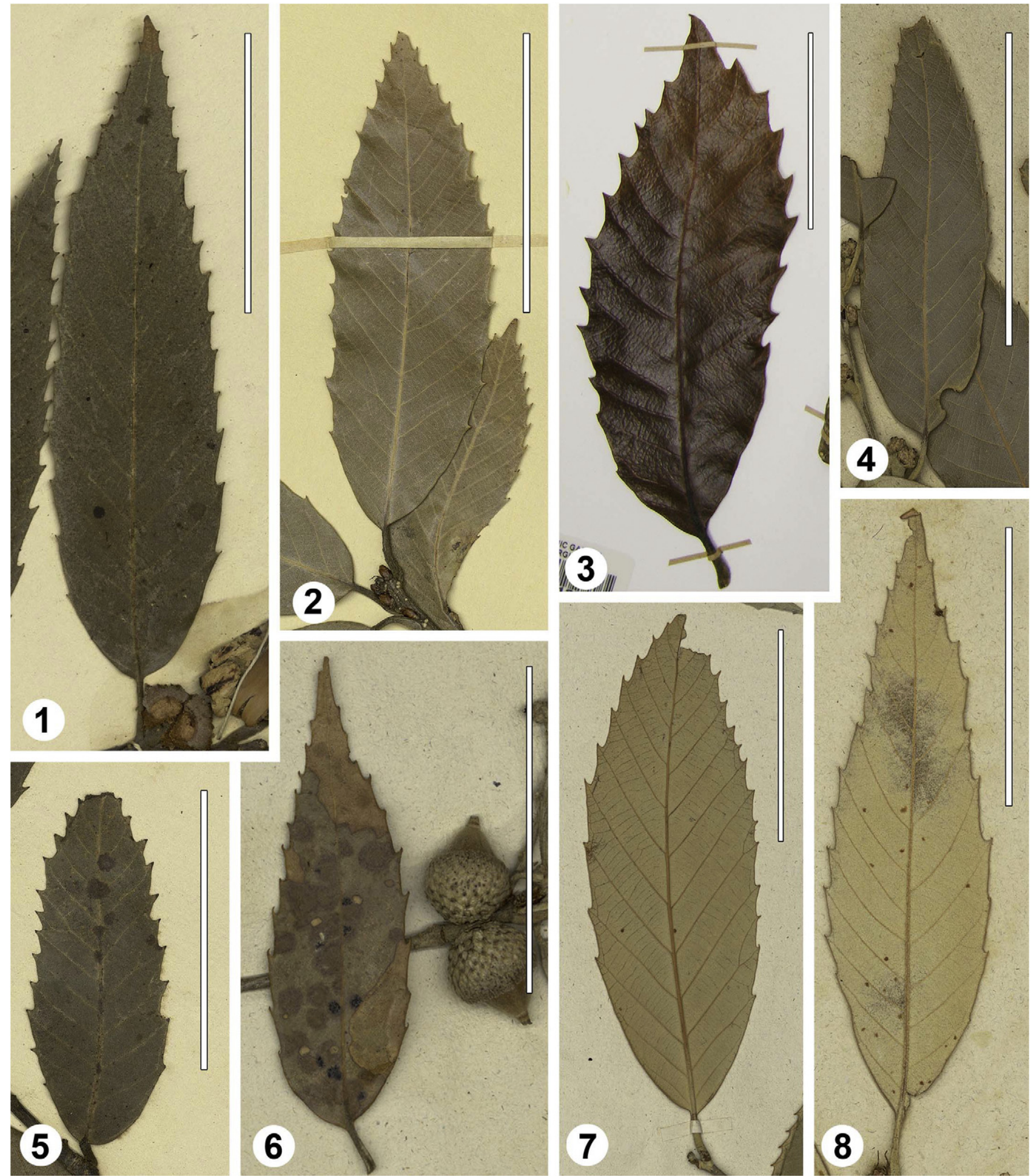

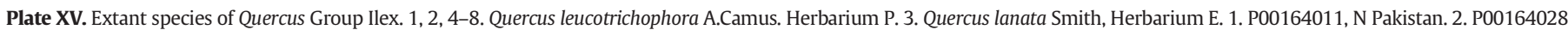
Nepal. 3. [M Minaki et al 9105137] W Nepal. 4. P00164025, N India. 5. P00164011, N Pakistan. 6. P00164021. 7. P00164023. 8. P00164019. Scale bar is 5 cm in 1-8. 

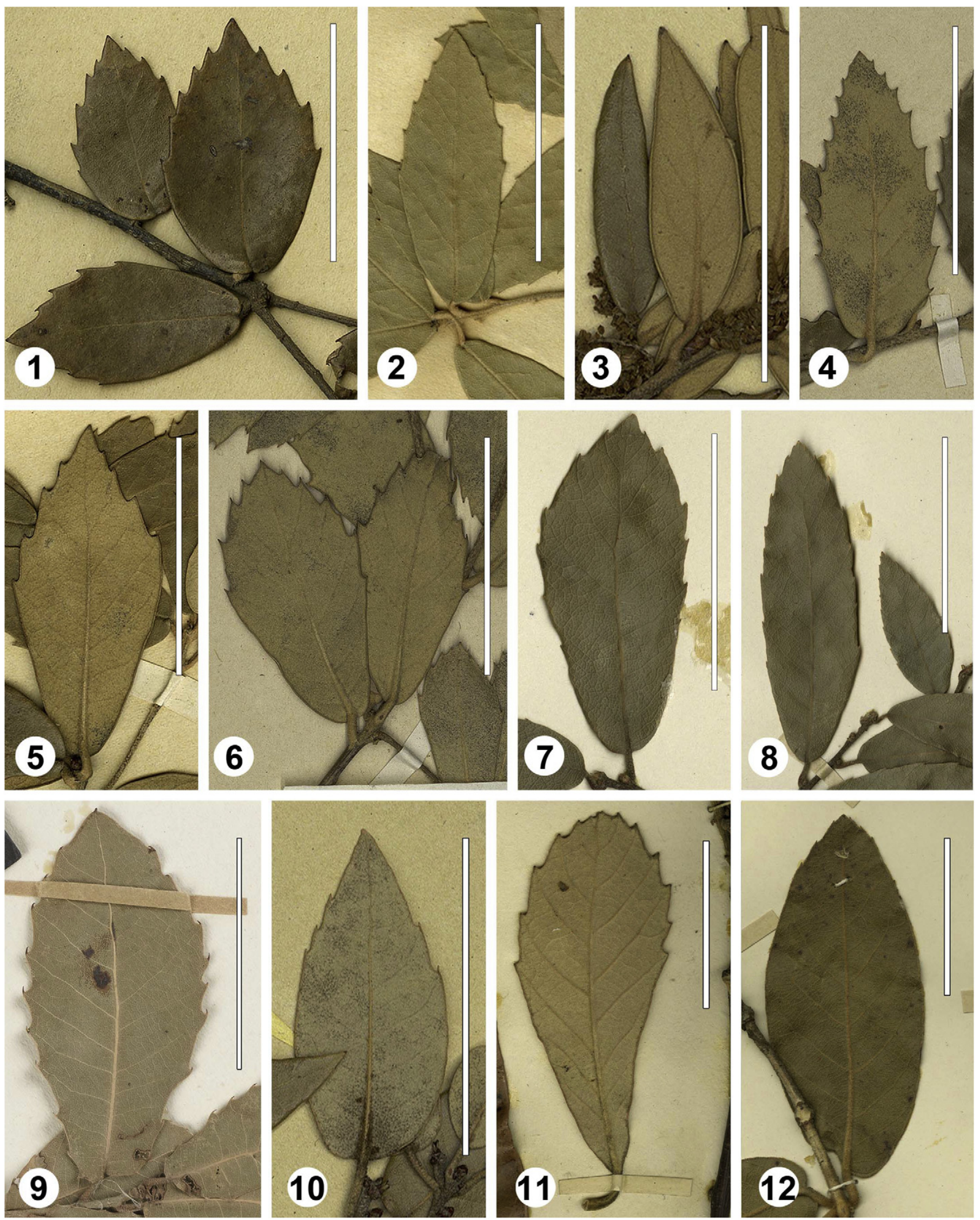

Plate XVI. Extant species of Quercus Group Ilex. 1-6. Ouercus acrodonta Seemen, Herbarium P. 1, 2, 5. P00721863, Hubei, China. 3. P06856596, Shaanxi, China 4. P06856603, Shaanxi, China. 6. P06856601, Shaanxi, China. 7, 8. Quercus cocciferoides Handel-Mazzetti. Herbarium E. E275420, NW Yunnan. 9. Quercus coccifera L. Herbarium E. E00404406, Israel. 10. Quercus handeliana A.Camus. Herbarium P. P06872352, Yunnan, China. 11. Quercus franchetii Skan. Herbarium E. E00275419, Yunnan, China. 12. Quercus oxyphylla (E.H.Wilson) Handel-Mazzetti. Herbarium E. E00275407, Anhui, China. Scale bar is $3 \mathrm{~cm}$ in 1-12. 
Quercus drymeja might be related to "less hairy species in mesophytic and broaleaved evergreen forests". A number of potential modern analogues of Quercus drymeja Floribunda MT recognized in the present study exactly match these criteria $(Q$. floribunda, $Q$. tarokoensis, $Q$. tatakaensis; see Deng et al., 2017, table 3). However, it needs to be kept in mind that within closely related species the type of indumentum may be very different (e.g. in Q. ilex, Q. alnifolia, Q. coccifera and Q. calliprinos; Deng et al., 2017). This suggests that particular indumentum types have evolved independently in different more or less closely related groups of oaks.

Molecular data suggest that the Mediterranean $Q$. aucheri, Q. alnifolia, $Q$. coccifera and $Q$. ilex share a common origin with the Himalayan Q. floribunda and Q. baloot (Denk and Grimm, 2010; Simeone et al., 2016). When viewed in a Eurasian context, Q. floribunda occurs nested in a group of East Asian Group Ilex oaks, which is sister to the western Eurasian Ilex oaks. Notably, Q. coccifera and the strongly pubescent Q. aucheri are genetically indistinguishable. This may suggest that the presence or absence of leaf pubescence is less useful to determine taxonomic relatedness than generally assumed.

Quercus drymeja and Q. mediterranea represent extinct member(s) of the Quercus Group Ilex lineage. The Güvem MT of the lower Miocene deposits of Güvem and Kimi might in principle also represent a taxon intermediary between Group Ilex and Cerris (cf. Denk and Grimm, 2010, for the molecular differentiation of Quercus Group Ilex and Group Cerris). Unambiguous fossil evidence for Group Cerris (early Oligocene, Russian Far East; Pavlyutkin et al., 2014) occurs later than for Group Ilex (middle Eocene, Hainan Island, southern China; Hofmann, 2010; Spicer et al., 2014), and all currently available molecular data indicate a (Miocene) budding scenario for the origin of Group Cerris from a Group Ilex stock (Denk and Grimm, 2010; Hubert et al., 2014; Hipp et al., 2015; Simeone et al., 2016).

A time-calibrated phylogeny of oaks based on eight nuclear gene regions ( six single-copy genes, the polymorphic ITS region, and the $2^{\text {nd }}$ and $3^{\text {rd }}$ intron of the CRC gene), clade-consensus sequences, and a set of analyses, each using a different dating constraint (Hubert et al., 2014) suggested a late Oligocene to early Miocene crown age of the Group Ilex-Group Cerris lineage, with the two western Eurasian and the two East Asian members of Group Ilex included in the study by Hubert et al. (2014) diverging shortly after. The estimates correspond well with the time of deposition of the Güvem and Kimi deposits and with changes in morphotype diversity during the Miocene. Floribunda MTs of early Miocene Turkish and Greek deposits have short petioles as in modern Q. floribunda, while late Miocene specimens of this MT have conspicuously long petioles. This could reflect the isolation and morphological lineage sorting of the western Eurasian populations from the common ancestor of Group Ilex. While the western Eurasian populations (Floribunda MT) went extinct during the course of the Pliocene, the Himalayan and East Asian populations persisted. It would be tempting to assume that Miocene populations of $Q$. mediterranea evolved directly into the modern populations of the sibling species $Q$. aucheri, $Q$. coccifera, and $Q$. ilex. But it is more likely that populations of both $Q$. drymeja and $Q$. mediterranea provided the stock for the three modern species as well as for some western Himalayan taxa; particularly with respect to the extreme morphological plasticity (Mount Olympus example, Plates IX to XII), the ambiguous climatic preference (summer-dry Csa climates, but also in Cfa climates), and the notable genetic diversity of the modern Q. ilex (e.g. Denk and Grimm, 2010; Simeone et al., 2016; Vitelli et al., 2017).

The Himalayan high-elevation species with leaves similar to Q. mediterranea are probably not closely related to the $Q$. drymejamediterranea complex. Leaf fossils very similar to modern Q. monimotricha, Q. semecarpifolia and others were recovered from 15 Ma deposits of the Namling Plateau, Tibet (Zhou et al., 2007), suggesting that this group of oaks had evolved by the middle Miocene and possibly before. Across their shared range, the modern $Q$. aucheri and Q. coccifera share genotypes with Q. ilex (Denk and Grimm, 2010; Vitelli et al., 2017), even in highly divergent, non-coding nuclear (ITS) and plastid (trnH-psbA) gene regions that have frequently been suggested as barcodes for species discrimination in plants. The three species can only be differentiated with the sequences of the highly divergent and polymorphic 5S intergenic spacer (Denk and Grimm, 2010). In the eastern Mediterranean region, Q. coccifera shares the plastid diversity of the Cypriotic endemic Q. alnifolia, which has clearly distinct nuclear signatures even when growing in mixed stands (Neophytou et al., 2011a, 2011b). Further east, the western Himalayan species are genetically distinct. Overall, this points to a (very) recent origin of $Q$. coccifera from the general western Eurasian stock of Quercus Group Ilex. Thus, the mediterranea-type leaves of Mediterranean and
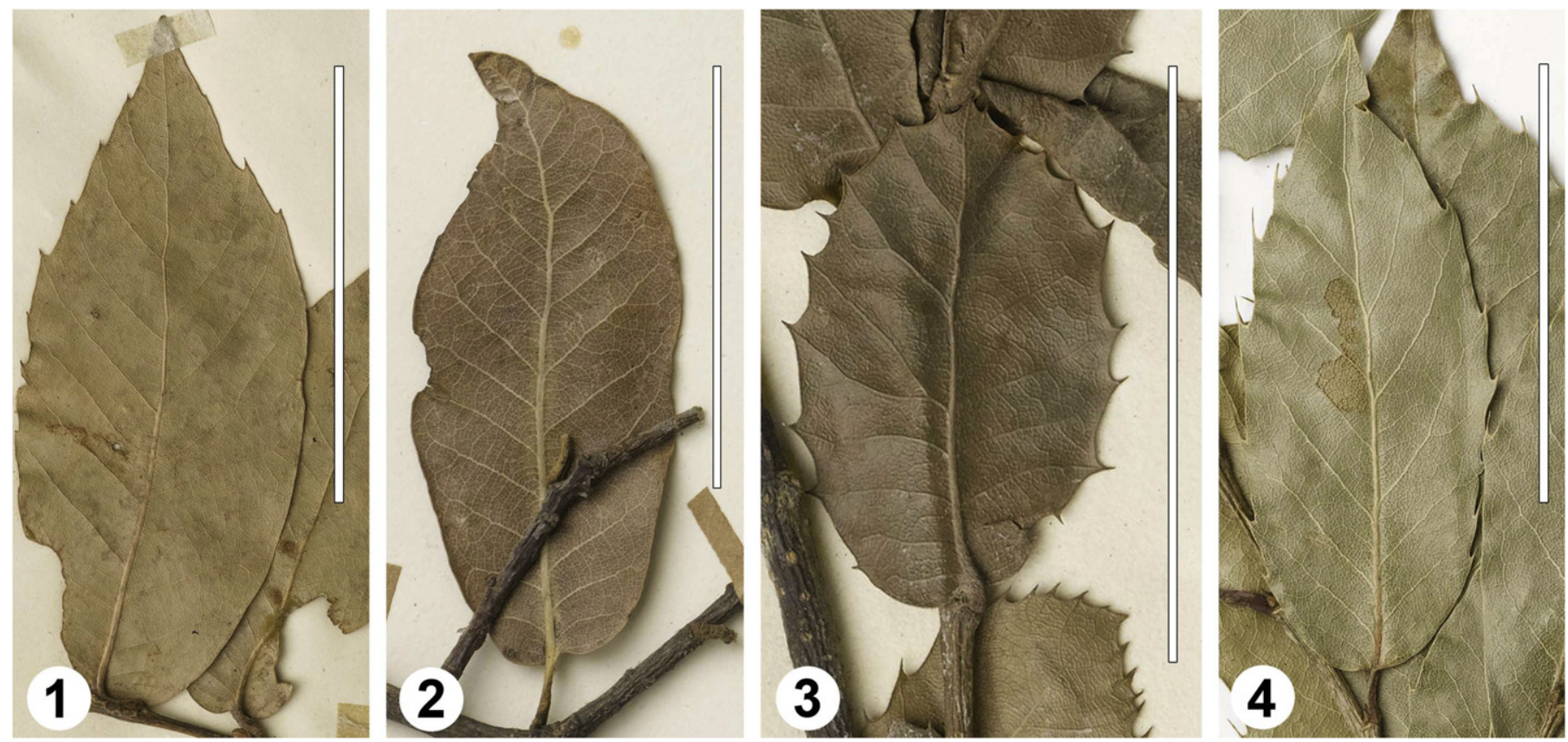

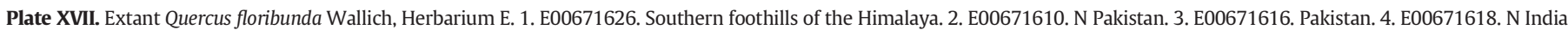
Scale bar is $5 \mathrm{~cm}$ in $1 ; 3 \mathrm{~cm}$ in 2-4. 
Eastern Himalayan species are most likely the result of convergent evolution.

\subsection{Earliest occurrences of sclerophyllous oaks in Eurasia}

The earliest unambiguous evidence of Quercus Group Ilex in western Eurasia are pollen grains from the early Oligocene of Central Europe (Denk et al., 2012) and leaf remains from the early Miocene of the eastern Mediterranean region (Paicheler and Blanc, 1981; Velitzelos et al., 2014). In East Asia, earliest unequivocal evidence of sclerophyllous oaks of Group Ilex is from the middle Eocene Changchang Formation, Hainan (Hofmann, 2010, dispersed pollen; Spicer et al., 2014, foliage). Possibly, Quercus Group Ilex was present in Yunnan (China) by the Oligocene (Zhou, 1993; Quercus haugii Colani, leaf fossils), but this record would need to be re-examined (the specimen figured in Writing Group of Cenozoic Plants of China, WGCPC, 1978, is a fragment of a leaf and is inconclusive regarding the taxonomic relationships of this leaf type). Leaf records of Quercus Group Ilex are common from Miocene deposits of East Asia (e.g. WGCPC, 1978; Zhou, 1993). At the time when Quercus Group Ilex established in Eurasia, sclerophyllous oaks were already represented by at least two related lineages in North America. Bouchal et al. (2014) found unequivocal evidence for Quercus Group Quercus/Lobatae and Group Protobalanus in the latest Eocene of Florissant, central U.S.A.

Paleogene leaf fossils previously included within Q. lonchitisQ. drymeja (Unger, 1852; Palamarev and Mai, 1998) were later transferred to the extinct genus Castaneophyllum Jones and Dilcher (Kvaček and Walther, 2012) based on leaf epidermal characteristics. These leaves also differ in gross morphology from the ones described here from Miocene deposits.

\subsection{Niche evolution in Eurasian sclerophyllous oaks}

Ackerly (2004) investigated adaptive leaf evolution in 12 lineages of Californian chaparral plants growing under distinct Mediterranean climate. Ten of the 12 chaparral plants originated from subtropical ancestors thriving in fully humid or summer-wet climates. Ackerly (2004) concluded that ancestors of chaparral plants were already pre-adapted and therefore were successful under Mediterranean (summer-dry) climates but had not necessarily evolved under Mediterranean climates. Table 4 summarizes the geographical, vertical and climatic distribution of modern species of Quercus Group Ilex, to which morphotypes of $Q$. drymeja and $Q$. mediterranea are compared in the present study. Quercus baloot, although not specifically compared to the fossil taxa is included as well, because it is considered to be closely related to both Q. floribunda and Q. coccifera (Simeone et al., 2016), connects the distribution ranges of these two species, and forms hybrids with $Q$. floribunda (Menitsky, 2005). Generally, the modern species have a large vertical range, with the exception of the Mediterranean $Q$. coccifera and the warm temperate to tropical Q. setulosa, both of which occur at lower elevations than the (typical) temperate species. Geographically, the species replace each other along a west-east and a north-south (in East Asia) axis. In addition, in the western range, different species are typical of certain altitudinal belts and ecologically distinct. For example, Q. baloot is markedly adaptable to different climate types, both in terms of seasonality and temperature extremes (Fig. SI 1). Quercus floribunda occurs in a vertical belt above $Q$. baloot in humid temperate climates (fully humid and summer-wet). To the east, Quercus floribunda is replaced by $Q$. lanata and $Q$. leucotrichophora occurring in similar climates and vegetation types (see Section 3.4). Still further east and northeast, $Q$. engleriana is also found in fully humid ( $C f$ climates) and less so in summer-wet climates ( $\mathrm{Cw}$ ). Quercus engleriana may occur together with Fagus and various Tertiary relicts such as Cercidiphyllum, Symplocos, Torreya, Zanthoxylum and Zelkova (Table SI 3). Finally, Q. setulosa extends to the lowland tropics occurring above tropical dipterocarp forest. Hence, speciation processes and niche evolution in

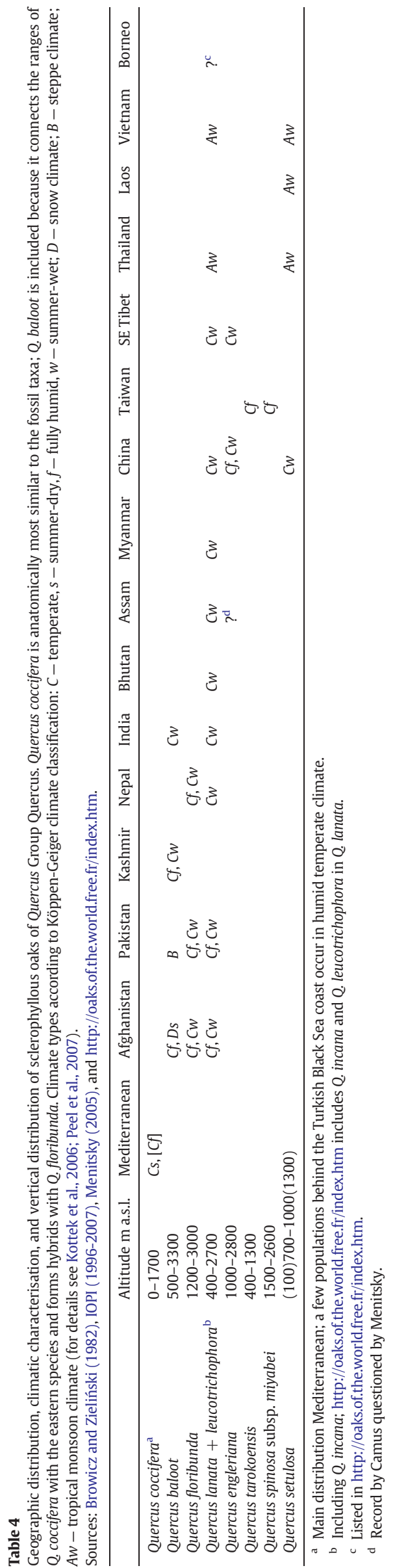


sclerophyllous oaks of Group Ilex were likely triggered by ecological differentiation and geographical distance.

In addition to the western Eurasian fossil taxa investigated here, leaf fossils related to modern sclerophyllous oaks of high elevations on the outer slopes of the Himalayas and of southwestern China (e.g. Q. semecarpifolia, Q. guyavifolia, Q. aquifolioides, Q. pannosa) occurred on an already elevated southern Tibet Plateau (Wang et al., 2008) and in the Hengduan Mountains during the Miocene and Pliocene (Zhou, 1992; Zhou et al., 2007). As in the case of the Californian chaparral the sclerophyllous evergreen leaf morphology of the ancestral species of Quercus Group Ilex appears to have facilitated ecological radiation into diverse habitats already during the Miocene.

\subsection{Palaeoecological implications}

Foliage of Quercus drymeja and in particular of Q. mediterranea has sometimes been connected to seasonally dry and Mediterranean climatic conditions or xerophytic plant communities (e.g. Berger, 1953a, Austria, Hernals, middle Miocene, as maquis and dry Mediterranean forest; Berger and Zabusch, 1952, Austria, Türkenschanz, middle Miocene, as Mediterranean maquis, savannah, and scrubland-steppe comparable to those in eastern and southern Africa; Berger, 1957b, Messinian Italy, as dry, light scrublands, savannah, and scrubland-steppe; Andreánszky, 1963, Hungary, middle Miocene, Erdöbénye, as Mediterranean sclerophyllous forest; Kvaček et al., 2002, Greece, late Miocene, Vegora, as ethesian summer-dry regime). Pollen with affinity to "Quercus ilex/ coccifera" is commonly considered to represent an ecological group of "Mediterranean sclerophyllous" or "xeric" elements (e.g. JiménezMoreno et al., 2005, 2008).

These interpretations overlooked that woody angiosperms with sclerophyllous leaves have long been considered as remnants of laurophyllous humid vegetation from which they evolved into various subhumid vegetation types (Axelrod, 1975; Palamarev, 1989; Mai, 1995; Ackerly, 2004). Palamarev (1967) and Axelrod (1975) suggested that the sclerophyllous flora evolved as an understory element of humid subtropical (mesophytic) forests or on specific substrates in the Eocene and that increased seasonality since the early Oligocene (see, for example, Zachos et al., 2001) further promoted sclerophyllous plants that began to form independent vegetation units. According to Palamarev (1967), the maximum rainfall occurred during the warm summer months and the shift to summer-dry conditions as currently found in the Mediterranean region occurred during the latest Miocene or Pliocene (see also Suc, 1984). With respect to the overall molecular differentiation patterns in Quercus Group Ilex and, in particular, its western Eurasian members (e.g. Denk and Grimm, 2010; Simeone et al., 2016; Vitelli et al., 2017), it appears very unlikely that a xerophytic evergreen oak lineage should have persisted from the Miocene ( $Q$. mediterranea) until today (Q. coccifera).

The results of the present study suggest that when members of Quercus Group Ilex (pollen and foliage) are dominating in Miocene plant assemblages of western Eurasia, they indicate substantial rainfall (Cfa-, Cwa-climates) but not summer draught. This explains why they commonly co-occur with humid temperate elements such as Fagus and Cathaya (e.g. Güvem-Keseköy; Vegora). Where they are rare or absent, Fagus also is rare or absent (e.g. Lesbos, Crete, possibly Soma). In the Miocene, this probably means aspect-wise drier stands (e.g. lee situations). This is in agreement with Kvaček et al.'s (2006) interpretation of what they called "subtropical sub-humid sclerophyllous forest". These authors clearly stated that these forests have nothing in common with the modern Mediterranean forest thriving under a summer-dry climate and instead suggested similarities with montane forests in drier parts of the Himalayas. It is difficult to pinpoint the origin of true Mediterranean sclerophyllous oaks $(Q$. coccifera, $Q$. aucheri, $Q$. ilex, Q. alnifolia). The late Pliocene flora of Atalanti (Lokris Basin, Central Greece; Velitzelos et al., 2014) still comprises "exotic" elements such as Fagus haidingeri and Quercus drymeja with Himalayan and East
Asian affinities. From the early Pleistocene of Rhodes and Zakynthos floras with high proportions of modern Mediterranean taxa have been reported and these may mark the origin of modern Mediterranean sclerophyllous oaks (Velitzelos et al., 2014).

\subsection{Conclusions}

We assessed taxonomic affinities of two widespread Neogene sclerophyllous oaks in western Eurasia. We notice that the inferred taxonomic relationships of the fossil leaf taxa Quercus drymeja (including Q. zoroastri) and $Q$. mediterranea have not changed much since the original description by Unger in the middle of the 19th century. Using leaf morphological characters of fossil and modern taxa, the available scattered information on leaf epidermal characteristics of the fossil taxa, and information from the record of dispersed pollen grains, we infer that both taxa represent a Eurasian infrageneric group of Quercus, Group Ilex, that occurs from western North Africa and southwestern Europe to Southeast Asia and Japan. In the light of leaf variation encountered in their modern relatives, we conclude that leaf remains assignable to $Q$. drymeja and $Q$. mediterranea may have belonged to a single species or to two or more species at different localities. This has implications for the usage of standardized modern analogue taxa to infer palaeoenvironments and palaeoclimate.

We also compared Miocene and Pliocene plant assemblages with sclerophyllous oaks of Group Ilex to modern vegetation containing morphologically closely related species. Analogous modern vegetation follows a humid transect of forest vegetation on the outer slopes of the Himalayas from northeastern Afghanistan to Nepal and into humid temperate China. This suggests that the two widespread sclerophyllous oaks $Q$. drymeja and $Q$. mediterranea indicate mostly general humid temperate conditions, fully humid or summer-wet, during the times when they were deposited rather than Mediterranean conditions as implied by their modern western Eurasian relatives.

Supplementary data to this article can be found online at http://dx. doi.org/10.1016/j.revpalbo.2017.01.005.

\section{Acknowledgements}

This study was supported by a grant from the Swedish Research Council (VR) to TD. GWG was funded by the Austrian Science Foundation, grant number M1751-B16. FG is funded by the Austrian Science Foundation, grant no. P24427-B25. Dianne Erwin kindly facilitated work in the plant fossil collections at UCMP, Berkeley, California; Andreas Hassler kindly provided specimens from his private collection of the Schaßbach locality, Austria. Henning Blom, Uppsala, is thanked for help with finding rare literature and Kathleen Pigg, Tempe, Arizona, for most valuable comments on the manuscript.

\section{References}

Ackerly, D.D., 2004. Adaptation, niche conservatism, and convergence: comparative studies of leaf evolution in the California chaparral. Am. Nat. 16, 3654-3671.

Akgün, F., Kayseri, M.S., Akkiraz, M.S., 2007. Palaeoclimatic evolution and vegetational changes during the Late Oligocene-Miocene period in the Western and Central Anatolia (Turkey). Palaeogeogr. Palaeoclimatol. Palaeoecol. 253, 56-90.

Andreánszky, G., 1963. Das Trockenelement in der jungtertiären Flora Mitteleuropas. Vegetatio 11, 155-172.

Arènes, J., Depape, G., 1956. La flore burdigalienne des îles Baléares (Majorque). Rev. Gén. Bot. 63, 347-390.

Axelrod, D.I., 1975. Evolution and biogeography of Madrean-Tethyan sclerophyll vegetation. Ann. Mo. Bot. Gard. 62, 280-334

Barrón, E., 1999a. Estudio paleobotánico del afloramiento vallesiense (Neógeno) del barranco de Salanca (la Cerdaña, Lérida, España). Aspectos paleoecológicos. Anales Jard. Bot. Madrid 57, 81-96.

Barrón, E., 1999b. Estudio paleobotánico, reconstrucción paleoambiental y aspectos tafonómicos del afloriamento vallesiense de Coll de Saig (La Cerdaña, Lérida, España). Rev. Esp. Paleontol. 77-88 Special volume "Homenaje al Prof. J. Truyols".

Berger, W., 1952a. Pflanzenreste aus dem miozänen Ton von Weingraben bei Drassmarkt (Mittelburgenland) II. Sitzung. Österr. Akad. Wiss. Math. Nat. Kl. 162, 17-24.

Berger, W., 1952b. Die altpliozäne Flora der Congerienschichten von Brunn-Vösendorf bei Wien. Palaeontogr. B 92, 79-121. 
Berger, W., 1953a. Pflanzenreste aus den obermiozänen Ablagerungen von Wien-Hernals Ann. Naturhist. Mus. Wien 59, 141-154.

Berger, W., 1953b. Jungtertiäre Pflanzenreste aus dem Gebiete der Ägäis (Lemnos Thessaloniki). Ann. Géol. Pays Hellén. 5, 34-65.

Berger, W., 1955a. Jungtertiäre Pflanzenreste aus dem unteren Lavanttal in Ostkärnten. Neues Jahrb. Geol. Palaontol. Abh. 100, 402-430.

Berger, W., 1955b. Nachtrag zur altpliozänen Flora der Congerienschichten von BrunnVösendorf bei Wien. Palaeontogr. B 97, 78-84

Berger, W., 1957a. Pflanzenreste aus dem Mittelmiozän (Helvet) des Teiritzberges bei Stetten in Niederösterreich. Ann. Naturhist. Mus. Wien 61, 90-95

Berger, W., 1957b. Untersuchungen an der obermiozänen (Sarmatischen) Flora von Gabbro (Monti Livornesi) in der Toskana. Palaeontogr. Ital. 51 (21), 1-96.

Berger, W., Zabusch, F., 1952. Die Pflanzenreste aus den obermiozänen Ablagerungen der Türkenschanze in Wien (Vorläufiger Bericht). Sitzung. Österr. Akad. Wiss. Math. Nat. Kl. 161, 499-507.

Bouchal, J., Zetter, R., Grímsson, F., Denk, T., 2014. Evolutionary trends and ecological differentiation in early Cenozoic Fagaceae of western North America. Am. J. Bot. 101 $1332-1349$

Boulay, N., 1887. Notice sur la flore tertiaire des environs de Privas (Ardèche). Bull. Soc. Geol. Fr. 34, 227-239 (255-279)

Bozukov, V., Utescher, T., Ivanov, D., Tsenov, B., Ashraf, A.R., Mosbrugger, V., 2011. New results for the fossil macroflora of the Beli Breg Lignite Basin, West Bulgaria. Phytol. Balcan. 17, 3-19.

Browicz, K., Zieliński, J., 1982. Chorology of Trees and Shrubs in South-West Asia and Adjacent Regions. 1. Polish Scientific Publishers, Warsaw.

Bůžek, C., Holý, F., Kvaček, Z., 1996. Early Miocene flora of the Cypris Shale (western Bohemia). Acta Mus. Nat. Pragae Ser. B Hist. Nat. 52, 1-72.

Deng, M., Jiang, X.-L., Song, Y.-G., Coombes, A., Yang, X.-R., Xiong, Y.-S., Li, Q.-S., 2017. Leaf epidermal features of Quercus Group Ilex (Fagaceae) and their application to species identification. Rev. Palaeobot. Palynol. 237, 10-36.

Denk, T., Grimm, G.W., 2009. Significance of pollen characteristics for infrageneric classification and phylogeny in Quercus (Fagaceae). Int. J. Plant Sci. 170, 926-940.

Denk, T., Grimm, G.W., 2010. The oaks of western Eurasia: traditional classifications and evidence from two nuclear markers. Taxon 59, 351-366.

Denk, T., Tekleva, M.V., 2014. Pollen morphology and ultrastructure of Quercus with focus on Group Ilex (=Quercus Subgenus Heterobalanus (Oerst.) Menitsky): implications for oak systematics and evolution. Grana 53, 255-282.

Denk, T., Tekleva, M.V., Zetter, R., Hofmann, C.-C., 2010. Importance of pollen characteristics for systematics of living and fossil oaks (Quercus, Fagaceae). Program and Abstracts, 8th European Palaeobotany-Palynology Conference 2010, Budapest, p. 78 .

Denk, T., Grímsson, F., Zetter, R., 2012. Fagaceae from the early Oligocene of Central Europe: persisting New World and emerging Old World biogeographic links. Rev. Palaeobot. Palynol. 169, 7-20.

Depape, G., 1928. Plantes fossiles des Iles Baléares (Gisements burdigaliens de Majorque) Ann. Soc. Géol. Nord 53, 13-19.

Draxler, I., Zetter, R., 1991. Palynologische Untersuchungen in den mittel-miozänen Hochriegelschichten (Süßwasserschichten) von Weingraben (Gemeinde Kaisersdorf, Burgenland, Österreich), pp. 71-92. Jubiläumsschrift 20 Jahre Geologische Zusammenarbeit Österreich-Ungarn. Geologische Bundesanstalt, Wien.

Engelhardt, H., 1903. Tertiärpflanzen von Kleinasien. Beitr. Paläont. Geol. Österr.-Ung. Or. Mitt. Paläont. Geol. Inst. Univ. Wien 15, 55-64.

Erdei, B., Hably, L., Selmeczi, I., Kordos, L., 2011. Palaeogene and Neogene localities in the North Hungarian Mountain Range. Stud. Bot. Hung. 42, 153-183.

Fischer, T.C., Butzmann, R., 2000. Die neogene Flora von Meleto (Valdarno, Italien), Paläobotanik, Paläoökologie und Paläoklima. Doc. Nat. Flora Tert. Mediterr. V 6 $1-187$.

Flora of China Editorial Committee, 1999. Flora of China, Cycadaceae Through Fagaceae. 4 Missouri Botanical Garden, St. Louis.

Flora of North America Editorial Committee, 1997. Flora of North America North of Mexico, 3. Oxford University Press, New York

Freitag, H., 1972. Die natürliche Vegetation Afghanistans. Beiträge zur Flora und Vegetation Afghanistans I. Vegetatio 22, 285-344.

Gaudin, C.T., Strozzi, C., 1859. Contributions à la flore fossile italienne. II. Val d'Arno. Nouv. Mémo. Soc. Helv. Sci. Nat. 17, 1-60.

Gemici, Y., Akyol, E., Seçmen, Ö., Akgün, F., 1990. Macro et microflore fossile du Bassin Néogène d'Eskihisar (Yatağan-Muğla). Ege Univ. J. Fac. Sci. B12, 29-41.

Gemici, Y., Akyol, E., Akgün, F., Seçmen, Ö., 1991. Soma kömür havzasi fosil makro ve mikroflorası. Maden Tektik Arama Dergisi 112, 161-178.

Gemici, Y., Akyol, E., Akgün, F., 1993. Sahınalı (Aydın) Neojen havzasinin fosil makro ve mikorflorasi. Doğa. Turk. J. Bot. 17, 91-106.

Givulescu, R., Ghiurca, V., 1969. Flora pliocen de la Chiuzbaia (Maramureș). Inst. Geol. Mem. 10, 1-81.

Govaerts, R., Frodin, D.G., 1998. World Checklist and Bibliography of Fagales (Betulaceae, Corylaceae, Fagaceae and Ticodendraceae). Royal Botanic Gardens, Kew.

Grímsson, F., Denk, T., Zetter, R., 2008. Pollen, fruits, and leaves of Tetracentron (Trochodendraceae) from the Cainozoic of Iceland and western North America and their palaeobiogeographic implications. Grana 47, 1-14.

Hipp, A.L., Manos, P., McVay, J.D., Cavender-Bares, J., González-Rodríguez, A., RomeroSeverson, J., Hahn, M., Brown, B.H., Budaitis, B., Deng, M., Grimm, G., Fitzek, E. Cronn, R., Jennings, T., Avishai, M., Simeone, M.C., 2015. A Phylogeny of the World's Oaks. http://2015.botanyconference.org/engine/search/index.php?func= detail\&aid $=1305$

Hofmann, C.-C., 2010. Microstructure of Fagaceae pollen from Austria (Paleocene/Eocene boundary) and Hainan Island (?middle Eocene). 8th European PalaeobotanyPalynology Conference. Hungarian Natural History Museum, Budapest, p. 119.
Huang, C., Zhang, Y., Bartholomew, B., 1999. Fagaceae. In: Wu, Z.-Y., Raven, P.H. (Eds.), Flora of China, Vol. 4: Cycadaceae Through Fagaceae. Science Press and Missouri Botanical Garden Press, Beijing and St. Louis, pp. 314-400.

Hubert, F., Grimm, G.W., Jousselin, E., Berry, V., Franc, A., Kremer, A., 2014. Multiple nuclear genes stabilize the phylogenetic backbone of the genus Quercus. Syst. Biodivers. 12, 405-423.

IOPI, 1996-2007. International Organization for Plant Information. Global Plant Checklist. Published on the Internet. http://www.bgbm.org/iopi/gpc/default.asp [last accessed 07/04/2016].

Jechorek, H., Kovar-Eder, J., 2004. Neue Taxa aus der Flora von Weingraben (Burgenland, Miozän, Badenium). Ann. Nat. Mus. Wien A 106, 327-343.

Jiménez-Moreno, G., Rodríguez-Tovar, F.J., Pardo-Igúzquiza, E., Fauquette, S., Suc, J.-P., Müller, P., 2005. High-resolution palynological analysis in late early-middle Miocene core from the Pannonian Basin, Hungary: climatic changes, astronomical forcing and eustatic fluctuations in the Central Paratethys. Palaeogeogr. Palaeoclimatol. Palaeoecol. 216, 73-97.

Jiménez-Moreno, G., Mandic, O., Harzhauser, M., Pavelić, D., Vranjković, A., 2008. Vegetation and climate dynamics during the early Middle Miocene from Lake Sinj (Dinaride Lake System, SE Croatia). Rev. Palaeobot. Palynol. 152, 237-245.

Kleinhölter, K., 1994. Zur stratigraphischen Einstufung der Platana-Formation im Pyrgosund Zachara-Becken (West-Peloponnes, Griechenland). Münster. Forsch. Geol. Paläont. 76, 263-270.

Knobloch, E., Kvaček, Z., 1976. Miozäne Blätterfloren vom Westrand der Böhmischen Masse. Rozpr. Ed. Ústavu Geol. 42, 1-131.

Knobloch, E., Kvaček, Z., 1996. Miozäne Floren der südböhmischen Becken. Sborn. Geol. Paleontol. 33, 39-77.

Knobloch, E., Velitzelos, E., 1986a. Die obermiozäne Flora von Likudi bei Elassona (Thessalien, Griechenland). Doc. Nat. 29, 5-20.

Knobloch, E., Velitzelos, E., 1986b. Die obermiozäne Flora von Prosilion bei Kozani (SüdMazedonien, Griechenland). Doc. Nat. 29, 29-33.

Kolakovsky, A.A., 1964. The Pliocene flora of Kodor. Sukhumi Bot. Gard. Monogr. 1, 1-200. Kolakovsky, A.A., Ratiani, N.K., 1967. The Pliocene flora of Maly Shirak. Trans. Bot. Gard. Sukhumi 16, 30-71.

Kottek, M., Grieser, J., Beck, C., Rudolf, B., Rubel, F., 2006. World map of the Köppen-Geiger climate classification updated. Meteorol. Z. 15, 259-263.

Kovar-Eder, J., Kvaček, Z., Meller, B., 2001. Comparing Early to Middle Miocene floras and probable vegetation types of Oberdorf near Voitsberg (Austria), Bohemia (Czech Republic), and Wackersdorf (Germany). Rev. Palaeobot. Palynol. 114, 83-125.

Kovar-Eder, J., Kvaček, Z., Ströbitzer-Hermann, M., 2004. The Miocene flora of Parschlug (Styria, Austria) - revision and synthesis. Ann. Naturhist. Mus. Wien 105 (A), 45-159.

Kováts, J., 1856. Fossile Flora von Erdőbénye. Arb. Geol. Ges. Ung. 1, 1-38.

Kutuzkina, E.F., 1964. Sarmatskaia flora Armavia. Paleobotanika 5, 148-229.

Kvaček, Z., Walther, H., 1989. Paleobotanical studies in Fagaceae of the European Tertiary. Plant Syst. Evol. 162, 213-229.

Kvaček, Z., Walther, H., 2012. European Tertiary Fagaceae with chinquapin-like foligae and leaf epidermal characteristics. Feddes Rep. 121, 248-267 (2010).

Kvaček, Z., Mihajlovíc, D., Vrabac, S., 1993. Early Miocene flora of Miljevina (Eastern Bosnia). Acta Palaeobot. 33, 53-89.

Kvaček, Z., Velitzelos, D., Velitzelos, E., 2002. Late Miocene Flora of Vegora Macedonia N. Greece. Koralis, Athens.

Kvaček, Z., Kováč, M., Kovar-Eder, J., Doláková, N., Jechorek, H., Parashiv, V., Kováčová, M., Sliva, L., 2006. Miocene evolution of landscape and vegetation in the Central Paratethys. Geol. Carpath. 57, 295-310.

Kvaček, Z., Teodoridis, V., Roiron, P., 2011. A forgotten Miocene mastixioid flora of Arjuzanx (Landes, SW France). Palaeontogr. B 285, 3-111.

Lazarević, Z., Milivojević, J., 2010. Early Miocene flora of the intramontane Žagubica Basin (Serbian Carpatho-Balkanides). N. Jb. Geol. Paläont. (Abh.) 256, 141-150.

Lincoln, R., Boxshall, G., Clark, P., 1998. A Dictionary of Ecology, Evolution and Systematics. Cambridge University Press, Cambridge.

Liu, Y.-S., Guo, S.-X., Ferguson, D.K., 1996. Catalogue of Cenozoic megafossil plants in China. Palaeontogr. B 238, 141-179.

Mai, D.H., 1995. Tertiäre Vegetationsgeschichte Europas. Gustav Fischer Verlag, Jena.

Mai, D.H., 2007. The floral change in the Tertiary of the Rhon mountains. Acta Palaeobot. 47, 135-143

Manos, P.S., Zhou, Z., Cannon, C.H., 2001. Systematics of Fagaceae: phylogenetic tests of reproductive trait evolution. Int. J. Plant Sci. 162, 1361-1379.

Martinetto, E., 2003. Leaves of terrestrial plants from the Pliocene shallow marine and transitional deposits of Asti (Piedmont, NW Italy). Boll. Soc. Paleontol. Ital. 42, 75-111.

Massalongo, A., Scarabelli, G., 1859. Studii sulla flora fossile e geologia stratigrafica del Senigaliese. Imola.

Menitsky, Y.L., 2005. Oaks of Asia. Science Publishers, Enflied, New Hampshire, USA.

Neophytou, C., Dounavi, A., Fink, S., Aravanopoulos, F., 2011a. Interfertile oaks in an island environment: I. High nuclear genetic differentiation and high degree of chloroplast DNA sharing between Q. alnifolia and Q. coccifera in Cyprus. A multipopulation study. Eur. J. For. Res. 130, 543-555.

Neophytou, C., Aravanopoulos, F.A., Fink, S., Dounavi, A., 2011b. Interfertile oaks in an island environment. II. Limited hybridization between Quercus alnifolia Poech and Q. coccifera L. in a mixed stand. Eur. J. For. Res. 130, 623-635.

Paicheler, J.-C., Blanc, C., 1981. La flore du basin lacustre miocène de Bes-Konak (Anatolie septentrionale, Turquie). Géol. Méditerr. 8, 19-60.

Palamarev, E., 1967. Xerotherme Elemente in der Tertiärflora Bulgariens und Aspekte zum Problem der Formierung der mediterranen Flora auf der Balkanhalbinsel. Abh. Zent. Geol. Inst. 10, 165-175. 
Palamarev, E., 1989. Paleobotanical evidences of the Tertiary history and origin of the Mediterranean sclerophyll dendroflora. Plant Syst. Evol. 162, 93-107.

Palamarev, E., Mai, D.H., 1998. Die paläogenen Fagaceae in Europa: Artenvielfalt und Leitlinien ihrer Entwicklungsgeschichte. Acta Palaeobot. 38, 227-299.

Palamarev, E., Tsenov, B., 2004. Genus Quercus in the late Miocene flora of Baldevo Formation (Southwest Bulgaria): taxonomical composition and palaeoecology. Phytol. Balcan. 10, 147-156.

Pavlyutkin, B.I., Chekryzhov, I.U., Petrenko, T.I., 2014. Geology and Floras of Lower Oligocene in the Primorye. Dalnauka, Vladivostok.

Peel, M.C., Finlayson, B.L., McMahon, T.A., 2007. Updated world map of the Köppen-Geiger climate classification. Hydrol. Earth Syst. Sci. 11, 1633-1644.

Pop, E., 1936. Flora Pliocenică dela Borsec. Universitatea Regele Ferdinand i Cluj, Facultatea de Ştiinţe, Cluj-Napoca (no. 1, 190 pp.).

Robles, S., Barrón, E., Cebolla, C., 2013. Estudio paleobotánico preliminar del afloramiento plioceno de Camp dels Ninots (Caldes de Malavella, Girona, España). Macroflora del sector de Can Argilera. Bol. R. Soc. Esp. Hist. Nat. Sec. Geol. 17, 75-89.

Rögl, F., 1999. Mediterranean and Paratethys. Facts and hypotheses of an Oligocene to Miocene paleogeography (short overview). Geol. Carpath. 50, 339-349.

Schmitt, H., Butzmann, R., 1997. Entrischenbrunn - Statistische Untersuchungen an einer neuen Florenfundstelle aus der Oberen Süßwassermolasse im Landkreis Pfaffenhofen a. d. Ilm. Doc. Nat. 110, 55-87.

Schroeder, F.-G., 1998. Lehrbuch der Pflanzengeographie. Quelle \& Mayer, Wiesbaden.

Schweigert, G., 1993. Die mittelmiozäne Flora (MN 7) von Steinheim am Albuch (Schwäbische Alb, Baden-Württemberg). Jh. Ges. Naturkde. Württemberg 148, 61-96.

Simeone, M.C., Grimm, G.W., Papini, A., Vessella, F., Cardoni, S., Tordoni, E., Piredda, R., Franc, A., Denk, T., 2016. Plastome data reveal multiple geographic origins of Quercus Group Ilex. PeerJ 4, e1897. http://dx.doi.org/10.7717/peerj.1897.

Song, Y.-C., Xu, G.-S., 2003. A scheme of vegetation classification of Taiwan, China. Acta Bot. Sin. $45,883-895$.

Sordelli, F., 1896. Studi sulla vegetazione di Lombardia durante i tempi geologici. Tipografia L. F. Cogliati.

Spicer, R.A., Herman, A.B., Liao, W., Spicer, T.E.V., Kodrul, T.M., Yang, J., Jin, J., 2014. Cool tropics in the Middle Eocene: evidence from the Changchang Flora, Hainan Island, China. Palaeogeogr. Palaeoclimatol. Palaeoecol. 412, 1-16.

Ströbitzer, M., 1999. Die fossilen Blattvergesellschaftungen von Lintsching (Tamsweger Becken, Salzburg, Miozän). Beitr. Paläontol. Österr. 24, 91-153.

Suc, J.-P., 1984. Origin and evolution of the Mediterranean vegetation and climate in Europe. Nature 307, 429-432.

Teodoridis, V., Kvaček, Z., Sami, M., Utescher, T., Martinetto, E., 2015. Palaeoenvironmental analysis of the Messinian macrofossil floras of Tossigniano and Monte Tondo (Vena del Gesso Basin, Romagna Apennines, Northern Italy). Acta Mus. Nat. Pragae Ser. B. Hist. Nat. 71, 249-292.

Unger, F., 1841-1847. Chloris protogæa. Beiträge zur Flora der Vorwelt. Engelmann, Leipzig.
Unger, F., 1850. Genera et species plantarum fossilium. Braunmüller, Wien.

Unger, F., 1852. Iconographia plantarum fossilium. Denkschr. Math. Naturwiss. Cl. Kaiserl. Akad. Wiss. 4, 73-118.

Unger, F., 1867. Die Fossile Flora von Kumi auf der Insel Euboea. Denkschr. Math. Naturwiss. Cl. Kaiserl. Akad. Wiss. 27, 27-90.

Velitzelos, D., 2002. Field guide to the Neogene of the island of Evia. Early Miocene flora of Kymi. Field guide. 6th European Palaeobotany-Palynology Conference. University of Athens.

Velitzelos, D., Bouchal, J.M., Denk, T., 2014. Review of the Cenozoic floras and vegetation of Greece. Rev. Palaeobot. Palynol. 204, 56-117.

Vitelli, M., Vessella, F., Cardoni, S., Pollegioni, P., Denk, T., Grimm, G.W., Simeone, M.C., 2017. Phylogeographic structuring of plastome diversity in Mediterranean oaks (Quercus Group Ilex, Fagaceae). Tree Genet. Genomes 13:3. http://dx.doi.org/10. 1007/s11295-016-1086-8.

von Ettingshausen, C., 1888. Die fossile Flora von Leoben in Steiermark. 1, 2. Theil Denkschr. Math. Nat. Cl. Kaiserl. Akad. Wiss. 54, 261-318 (319-384).

Wang, C., Zhao, X., Liu, Z., Lippert, P.C., Graham, S.A., Coe, R.S., Yi, H., Zhu, L., Liu, S., Li, Y., 2008. Constraints on the early uplift history of the Tibetan Plateau. Proc. Natl. Acad. Sci. 105, 4987-4992.

Writing Group of Cenozoic Plants of China (WGCPC), 1978. Cenozoic plants from China. Fossil Plants of China 3. Science Press, Beijing (in Chinese).

Yang, K.-C. Lin, J.-K, Hsie, C.-F, Huang, C.-L, Chang Y.-M., Kuan, L--H., Su, J.-F., Chiu, S.-T. 2008. Vegetation pattern and woody species composition of a broad-leaved forest at the upstream basin of Nantzuhsienhsi in mid-southern Taiwan. Taiwania 53 325-337.

Zachos, J.C., Pagani, M., Sloan, L., Thomas, E., Billups, K., 2001. Trends, rhythms, and aberrations in global climate 65 Ma to present. Science 292, 686-693.

Zetter, R., 1989. Methodik und Bedeutung einer routinemäßigen kombinierten lichtmikroskopischen und rasterelektronenmikroskopischen Untersuchung fossiler Mikrofloren. Cour. Forschungsinst. Senck. 109, 41-50.

Zhou, Z., 1992. A taxonomical revision of fossil evergreen sclerophyllous oaks from China. Acta Bot. Sin. 34, 954-961.

Zhou, Z., 1993. The fossil history of Quercus. Acta Bot. Yunnanica 15, 21-33.

Zhou, Z., Yang, Q., Xia, K., 2007. Fossils of Quercus sect. Heterobalanus can help explain the uplift of the Himalayas. Chin. Sci. Bull. 52, 238-247.

Zidianakis, G., Mohr, B.A.R, Fassoulas, C, 2007. A late Miocene leaf assemblage from Vrysses, western Crete, Greece, and its paleoenvironmental and paleoclimatic interpretation. Geodiversitas 29, 351-377.

Zidianakis, G., Iliopoulos, G., Fassoulas, C., 2010. A new late Miocene plant assemblage from Messara Basin (Crete, Greece). Proceedings of the 12th International Congress. Bulletin of the Geological Society of Greece 63, pp. 781-792. 